\title{
Contourite depositional systems along the Mozambique channel: The interplay between bottom currents and sedimentary processes
}

\author{
Thiéblemont Antoine 1, 2, ", Hernández-Molina F. Javier ${ }^{1}$, Miramontes Elda ${ }^{3}$, Raisson François ${ }^{2}$, \\ Penven Pierrick ${ }^{4}$
}

\begin{abstract}
1 Department of Earth Sciences, Royal Holloway, University of London, Egham, Surrey, TW20 0EX, UK
2 TOTAL, R\&D Frontier Exploration Program, Avenue Larribau, Pau, 64000, France

3 UMR 6538 CNRS-UBO, IUEM, Laboratoire Géosciences Océan, Plouzané, 29280, France

4 UMR 6523 CNRS, IFREMER, IRD, UBO, Laboratoire d'Océanographie Physique et Spatiale, Plouzané, 29280, France

* Corresponding author : Antoine Thiéblemont, email address : athieblemont@gmail.com
\end{abstract}

\begin{abstract}
:
We present a combined study of the geomorphology, sedimentology, and physical oceanography of the Mozambique Channel to evaluate the role of bottom currents in shaping the Mozambican continental margin and adjacent Durban basin. Analysis of 2D multichannel seismic reflection profiles and bathymetric features revealed major contourite deposits with erosive (abraded surfaces, contourite channels, moats, furrows and scours), depositional (plastered and elongated-mounded drifts, sedimentary waves), and mixed (terraces) features, which were then used to construct a morphosedimentary map of the study area. Hydrographic data and hydrodynamic modelling provide new insights into the distribution of water masses, bottom current circulation and associated processes (e.g., eddies, internal waves, etc.) occurring along the Mozambican slope, base-of-slope and basin floor. Results from this work represent a novel deep-sea sedimentation model for the Mozambican continental margin and adjacent Durban basin. This model shows 1) how bottom circulation of water masses and associated sedimentary processes shape the continental margin, 2) how interface positions of watermasses with contrasting densities (i.e., internal waves) sculpt terraces along the slope at a regional scale, and 3) how morphologic obstacles (seamounts, Mozambique Ridge, etc.) play an essential role in local water mass behaviours and dynamics. Further analysis of similar areas can expand understanding of the global role of bottom currents in deep-sea sedimentation.
\end{abstract}




\section{Highlights}

- Combined study of the geomorphology, sedimentology, and physical oceanography of the Mozambique Channel. Bottom circulation of water masses and associated sedimentary processes shape the continental margin. - Interface positions of water-masses with contrasting densities (i.e., internal waves) sculpt terraces along the slope at a regional scale. Morphologic obstacles play an essential role in local water mass behaviours and dynamics.

Keywords : Contourites, Bottom currents, Sedimentary processes, Water mass interfaces, Continental margin, Mozambique channel 

Contour-following currents generated by thermohaline circulation are common processes that affect

34 continental margins and abyssal plains of the world's oceans (e.g., Stow, 1994; Faugères et al., 1999; Stow et 35 al., 2002, 2009; Rebesco and Camerlenghi, 2008; Rebesco et al., 2014). Deposits generated by along-slope 36 currents are known as 'contourites' or 'contourite drifts' (see McCave and Tucholke, 1986; Rebesco and Stow, 
2001). 'Erosional features' (e.g., abraded surfaces, contourite channels, contourite moats) are locally developed in association with contourite drifts in areas traversed by higher velocity current cores (e.g., García et al., 2009; Cattaneo et al., 2017). In some settings, 'mixed features' develop due to long-term depositional and erosional phases that form contourite terraces (e.g., Viana et al., 2007; Hernández-Molina et al., 2009, 2017a). Other settings host interactions between along-slope (contourites) and across-slope gravity-driven processes (turbidity currents and mass transport deposits). These processes may form 'hybrid features' (e.g., Creaser et al., 2017; Hernández-Molina et al., 2017b; Sansom, 2018). The range of depositional, erosional and mixed (erosional-depositional) features associated with a particular water mass can be interpreted as a 'Contourite Depositional System' (CDS). Continental margins host a number of CDSs associate to a water mass within a given depth range.

Recent studies have demonstrated the effectiveness of combining oceanographic analysis and geomorphologic approaches in interpreting CDSs (e.g., western South Atlantic margin: Preu et al., 2013; Hernández-Molina et al., 2016a; Gulf of Cadiz: Hernández-Molina et al., 2016b; Mediterranean Sea: Cattaneo et al., 2017). However, CDSs can become difficult to decipher (e.g., Hernández-Molina et al., 2006a) in the case of interactions of several different water masses, intermittent oceanographic processes (e.g., eddies, internal waves), and / or complex physiography. These special cases remain less understood due to lack of direct observations (Rebesco et al., 2014).

Since initial publication of studies on current-controlled sedimentation along the southern Mozambique basin (e.g., Kolla et al., 1980; 6, Fig. 1A), the southwestern region of the Indian Ocean and its CDSs have enjoyed growing scientific interest (Fig. 1A). To date, deposits directly linked to bottom current action have been described from at least eight different locations (Fig. 1A). The largest features are associated with water masses formed from Antarctic and sub-Antarctic sources. These include features along the northeastern Agulhas Ridge and Cape Rise seamounts (Gruetzner and Uenzelmann-Neben, 2015; 1, Fig. 1A), contourite drifts of the Transkei, which include the Oribi drift, M-drift (Niemi et al., 2000; 3, Fig. 1A), and Agulhas drift (Schlüter and Uenzelmann-Neben, 2008; 3, Fig. 1A), features along the southern Mozambique Ridge (Uenzelmann-Neben et al., 2011; 7, Fig. 1A), features along the Agulhas Plateau and Passage (Uenzelmann-Neben, 2001; Uenzelmann-Neben and Huhn, 2009; 2 and 8, Fig. 1A), and features along the continental margin of Mozambique off the Limpopo River (Preu et al., 2011; 5, Fig. 1A). In summary, these 
studies link the development of contourite features to particular water masses and water depth ranges.

Despite the strong influence that circulation exerts on sedimentary processes (e.g., Wiles et al., 2014, 2017; Breitzke et al., 2017), long stretches of the East African continental margin have not been interpreted in terms of their depositional processes. This paper presents novel analysis of water mass influence on seafloor morphology to interpret CDSs along the East African continental margin between the latitudes of $15^{\circ} \mathrm{S}$ and $30^{\circ}$ $S$ (hereafter the Mozambique Channel). The primary aims of this work are 1) to identify the main regional sedimentary features related to bottom current action, 2) to generate a regional morpho-sedimentary map of the Mozambique Channel and 3) to interpret the interplay between sedimentary and oceanographic processes.

\section{Regional setting}

\subsection{Geologic setting}

The Mozambique Channel is located in the southwest Indian Ocean between the East African continental margin of Mozambique and Madagascar (Fig. 1A). It developed during the break-up of East Gondwana (i.e., Madagascar, India, Antarctica, and Australia) and West Gondwana (i.e., Africa and South America) (McElhinny, 1970; McKenzie and Sclater, 1971). Rifting began in the Early-Middle Jurassic (183 - 177 Ma; Eagles and König, 2008) with the opening of the northern Mozambique basin (159 Ma to 124 Ma; Jokat et al., 2003; König and Jokat, 2010; Leinweber and Jokat, 2012; Leinweber et al., 2013) and persisted to the Early Cretaceous opening of the southern Mozambique Basin (124 Ma to 84 Ma; Gradstein et al., 2012) and the Natal Valley (135 Ma to 115 / 90 Ma; Goodlad et al., 1982; Watkeys and Sokoutis, 1998). Currently, the Mozambique Channel consists of three major basins: the northern Mozambique basin, the southern Mozambique basin, and the Durban basin (Fig. 1B). The northern Mozambique basin is bounded by the East African continental margin of Mozambique to the west and by the Davie Fracture Zone (DFZ) to the east. The DFZ developed during southerly movement of East Gondwana (including Madagascar) (Coffin and Rabinowitz, 1987, 1992) and was later reactivated by extensional deformation (e.g., Lacerda Graben) since the late Miocene (Mougenot et al., 1986). A group of isolated carbonate platforms (e.g., Bassas Da India) formed in the middle of the northern Mozambique basin from the Paleocene to early Miocene (Courgeon et al., 2016). Late Miocene-early Pliocene cessation of carbonate deposition and initiation of graben formation along the DFZ 
92

93

94

95

appears to be coeval and spatially linked with the development and propagation of the East African Rift System (Franke et al., 2015). The southern Mozambique basin is bounded to the west by the Mozambique Ridge (MozR), which occurs about $100 \mathrm{~km}$ off the coast, and to the east by the Madagascar Ridge (MdgR) (Fig. 1B). Both ridges are interpreted to represent a large igneous province of oceanic origin (Sinha et al., 1981; Fischer et al., 2017) forming between 140 and 122 Ma for the Mozambique Ridge (König and Jokat, 2010). Finally, the Durban basin represents the eastern termination of a major east-west trending fault system, the AgulhasFalkland Fracture Zone (Broad et al., 2006).

Open marine sedimentation began in the Early Cretaceous for the northern and southern Mozambique basins and in the Late Cretaceous for the Durban basin (Davison and Steel, 2017). Over the past $30 \mathrm{Ma}$, the areas of interest have experienced significant periods of middle Oligocene, middle Miocene, and late Pliocene hinterland uplift (Castelino et al., 2015). Periods of uplift are associated with increase in sediment transport to the adjacent basins along the southwestern Indian Ocean (Walford et al., 2005; Wiles et al., 2014; Castelino et al., 2015; Hicks and Green, 2016). Sediment delivery to the Mozambique Channel is complex and related to global eustatic changes and hinterland tectonics (Walford et al., 2005; Castelino et al., 2015; Hicks and Green, 2016; Wiles et al., 2017). Sediments are primarily sourced from the adjacent Zambezi river (present-day catchment of $1.39 \cdot 10^{6} \mathrm{~km}^{2}$ ), Limpopo river (present-day catchment of $4.15 \cdot 10^{5} \mathrm{~km}^{2}$ ), and Tugela river (present-day catchment of $2.91 \cdot 10^{4} \mathrm{~km}^{2}$ ) (Fig. 1A). These control the general sediment type and flux delivered to the Mozambique Channel over time.

\subsection{Oceanographic framework}

The south Indian Ocean hosts a variety of water masses characterized by different hydrographic properties as summarized in Table I. At present, oceanic circulation along the Mozambique Channel consists primarily of the southward flowing Mozambique current and the northward flowing Mozambique undercurrent (De Ruijter et al., 2002). The Mozambique current is part of the Agulhas current system (Lutjeharms, 2006) and is characterized by anticyclonic eddies with diameters of $\sim 300 \mathrm{~km}$ (Fig. 2). Four to six anticyclonic eddies per year occur in the Channel, and propagate southwards at $\sim 3-6 \mathrm{~km} / \mathrm{day}$ (de Ruijter et al., 2002; Schouten et al., 2003; Halo et al., 2014). The Mozambique current carries Tropical Surface Water, Subtropical Surface Water (TSW and STSW, < $200 \mathrm{~m}$ water depth, wd), the South Indian Central Water (SICW, 
between 200 and $600 \mathrm{~m}$ wd) (De Ruijter et al., 2002), and the northwest Indian-origin Red Sea Water (RSW, $900-1200 \mathrm{~m}$ wd) (Donohue et al., 2000; Beal et al., 2000; Swart et al., 2010). The Mozambique and Agulhas undercurrents flow northward along the Mozambican continental slope (Fig. 2) carrying Antarctic Intermediate Water (AAIW, 800 - $1500 \mathrm{~m}$ wd) after its westward flow over the Madagascar ridge (Fine, 1993) and the North Atlantic Deep Water (NADW, 2200 - 3500 m wd), which flows into the Natal Valley (Toole and Warren, 1993) towards the southern Mozambique basin, south of the Mozambique Ridge. A portion of the NADW flows into the southern Mozambique basin across deep corridors within the Mozambique Ridge (Wiles et al., 2014). The upper volume of the NADW crosses a sill in the northern Mozambique basin to enter the Somali Basin, while the remaining NADW flows along the eastern boundary of the northern Mozambique basin with a southerly returning current (van Aken et al., 2004; Ullgren et al., 2012). The Antarctic Bottom Water (AABW) circulates below $4000 \mathrm{~m}$ wd (Fig. 2). It flows northward as a western boundary current along the southern Mozambique basin (Tucholke and Embley, 1984; Read and Pollard, 1999). Because the basin is closed in the north, the AABW is deflected to form a southerly flowing boundary current along the east flank of the southern Mozambique basin (Kolla et al., 1980).

\section{Data and methods}

This study utilizes bathymetry, multichannel 2D seismic reflection profiles, hydrographic data, and hydrodynamic modelling. A slope gradient map was generated using GEBCO 2014 (Weatherall et al., 2015). The bathymetric base map included data from previous works of Wiles et al. $(2014,2017)$ and Breitzke et al. (2017), which were used to generate the morpho-sedimentary map. acquired for the Mozambique basin during 2013 / 2014 geophysical cruises by WesternGeco. This primary dataset represents a regional grid of linear, $36179 \mathrm{~km}$ MCSs spaced at approximately 10 to $70 \mathrm{~km}$ intervals. Profiles were migrated in time. A second dataset was acquired for the Durban basin in 2013 - 2014 by CGG.

142 The secondary dataset consists of widely spaced arrays spanning $6920 \mathrm{~km}$ and including 17 strike lines and 25 dip lines. The data were processed with Kirchhoff pre-stack time migration. Major morpho-sedimentary features were identified and mapped using bathymetry and seismic profiles. 
(WOD13; https://www.nodc.noaa.gov/OC5/WOD13/) and a Regional Oceanic Modelling System (ROMS, version CROCO: https://www.croco-ocean.org/).

Hydrographic data from WOD13 was used to create combined hydrographic and seismic cross sections.

Due to the lack of hydrographic sections, we constructed cross-slope sections by combining all available conductivity, temperature, salinity, and depth (CTD) stations and then projecting water sample stations onto the seismic cross-section at distances of up to $50 \mathrm{~km}$. The cross-sections were created using Ocean Data View (Schlitzer, 2013). CTD data were also used for generating potential temperature-salinity diagrams in order to identify water masses present along the Mozambique Channel.

The Regional Oceanic Modelling System (ROMS, CROCO version), a three dimensional ocean model described by Shchepetkin and McWilliams (2005), was used to simulate the bottom currents in the Mozambique Channel. ROMS is a primitive equation model that can estimate basin-scale, regional and coastal oceanic processes at high resolution (Shchepetkin and McWilliams, 2005). ROMS uses a topography following vertical grid allowing explicit resolution of interactions between bottom topography and ocean dynamics. The model used the GEBCO 2014 (Weatherall et al., 2015) bathymetric base map smoothed for numeric constraints. The model simulation ran for 21 years (from 1993 to 2014). The model surface conditions are derived from the ERA Interim atmospheric reanalysis (Dee et al., 2011) using a bulk formulation (Fairall et al., 1996). The lateral boundary conditions are drawn from a global ocean reanalysis GLORYS (Ferry et al., 2012). To reach a high resolution $1 / 36^{\circ}(\sim 3 \mathrm{~km})$ in the Mozambique Channel, three levels of embedded grids are used, based on the AGRIF two-way nesting method (Debreu et al., 2012). Since the mean kinematic bottomshear-stress induced by tides affects only the shelf (i.e., Bight of Sofala; Chevane et al., 2016), barotropic tides were not introduced in the model for this simulation.

Three cross-slope hydrographic sections based on CTD stations from northern, central, and southern sector water columns were used to interpret relations between water mass stratification and sedimentary features along the continental margin. Combining these sections with potential salinity-temperature-oxygen diagrams from the same dataset allowed us to identify the main water masses in each physiographic domain. 
172

173

174

175

176

177

178

identification of water masses and their spatial correlation with seafloor morphology can elucidate longer-

term oceanographic and sedimentary processes (Hernández-Molina et al., 2016a). Calculated as the oscillation frequency of a parcel displaced vertically in a statically stable environment, the buoyancy or Brunt-Väisälä frequency $(N)$ provides information on water column stratification (Da Silva et al., 2009). It is calculated from hydrographic data (World Ocean Database 2013) as:

$$
N=\sqrt{\frac{g}{\rho} \frac{\partial \rho}{\partial z}}
$$

where $g$ is the gravitational acceleration, $\rho$ is the density, and $\frac{\partial \rho}{\partial z}$ is the vertical density gradient.

This analytical approach identified numerous bottom current-controlled depositional and erosional features. We use the term 'contourites' for sediments deposited or substantially reworked by the persistent action of bottom currents (Faugères and Stow, 2008). This term includes a large variety of sediments affected by different types of currents (Rebesco et al., 2014). Thick, extensive sedimentary accumulations are defined as 'contourite drifts' or 'drifts'. Interpretation of features followed criteria for drift morphology and internal configuration detailed in McCave and Tucholke (1986), Faugères et al. (1999), Rebesco and Stow (2001), Rebesco (2005), and Rebesco et al. (2014).

\section{Results}

\subsection{Physiography of the study area}

The Mozambique Channel includes three major physiographic provinces, as defined by IHO and IOC (1983): the continental shelf, the continental slope and the abyssal plain (Fig. 3). All three margin provinces were interpreted from southern, central, and northern sectors of the study area. These represent the Tugela, Limpopo, and Zambezi Rivers discharge areas, respectively (Fig. 1A).

The continental shelf exhibits an average gradient of $0.4^{\circ}$. It is particularly narrow $(\sim 2-15 \mathrm{~km}$ in width) compared to the global average of $\sim 50 \mathrm{~km}$ (Shepard, 1963), except in the regions in front of the Tugela, Limpopo and Zambezi rivers (i.e., $51 \mathrm{~km}, 80 \mathrm{~km}$ and $130 \mathrm{~km}$ respectively) (Fig. 3). The continental slope is bordered to the west by the shelf-break, which is around $50-120 \mathrm{~m}$ water depths (set at $\sim 200 \mathrm{~m}$ wd in this study). In the study area, the continental slope exhibits a relatively gentle gradient $\left(1.1^{\circ}\right.$ on average) relative to 
the global average slope $\left(3^{\circ}\right.$, Kennett, 1982). The slope divides into upper, middle, and lower subdomains. Each subdomain was defined to highlight zones of abrupt changes in seabed gradient (Fig. $\mathbf{3}$ and Table II); the upper, middle and lower slope, respectively, have an average gradient of: $1.6^{\circ}, 1.1^{\circ}$ and $0.9^{\circ}$, and occur between isobaths of: 200 to $1000 \mathrm{~m}, 1000$ to $1600 \mathrm{~m}$, and 1600 to $2400 \mathrm{~m}$. The morphological seafloor changes that determine the upper, middle and lower slope subdomains roughly coincide with the distribution of large-scale flatter areas or terraces. These terraces have been described and locally characterized by Martin (1981) in the central sector: the Inharrime terrace $(<800 \mathrm{~m} \mathrm{wd})$ and the Central terrace $(\sim 1400-2000 \mathrm{~m} w \mathrm{w})$, which are separated by the SW-NE rough topography of the Almirante Leite Bank. Furthermore, a broad ( 90 $\mathrm{km}$ ) gently seaward dipping $\left(0.3^{\circ}\right)$ terrace occurs around $21^{\circ} \mathrm{S}(1300-1600 \mathrm{~m}$ wd) that has been described by Wiles et al. (2017) (Fig. 3). In this study, the base-of-slope is set at $2400 \mathrm{~m}$ water depth (wd). In areas where the buried Beira High and the Mozambique Ridge abut the continental slope (i.e., $21^{\circ} \mathrm{S}$ to $29^{\circ} \mathrm{S}$ ), a steep surface $\left(2-10^{\circ}\right)$ develops at the foot of the lower slope (from $\sim 2400 \mathrm{~m}$ wd) (Fig. 3). In this study, this feature belongs to the abyssal plain province.

The abyssal plain of the southern sector (i.e., Natal Valley) lies between 2400 m (uppermost, narrowest part) and $\sim 3000 \mathrm{~m}$ wd (southward at $\sim 31^{\circ} \mathrm{S}$ ). This feature is bounded to the east by the Mozambique Ridge, which rises to a depth of 1800 m (Fig. 3). The Mozambique Ridge deepens along E-W oriented pathways (at depths of $\sim 2000-3000 \mathrm{~m}$ wd) connecting the abyssal plain regions of the Natal Valley and the southern Mozambique basin. The abyssal plain depth of the Mozambique basin in the northern and central sector increases from $\sim 2400 \mathrm{~m}$ to $\sim 4000 \mathrm{~m}$ wd southward at $\sim 27^{\circ} \mathrm{S}$. The large-scale morphology of the abyssal plain includes numerous seamounts (i.e., Bassas Da India and Boucart) (Fig. 3).

\subsection{Gravitational features}

The continental slope of the southern sector hosts numerous submarine canyons extending from the upper slope to the distal limit of the lower slope. Northward (and south of the Tugela canyon), submarine canyons only occur within the lower slope (Fig. 4). Tugela canyon obliquely crosscuts the continental slope and feeds the Tugela Cone, a deep-water fan complex (Fig. 4). The canyon reaches widths of up to $19 \mathrm{~km}$ and incision depths of up to $1000 \mathrm{~m}$ in the middle slope. The canyon lacks any form of connection with the modern 
224

225

226

227

228

229

230

231

232

233

234

235

236

237

238

239

240

241

242

243

deepens downslope to $2320 \mathrm{~m}$ wd with incision depths of up to $250 \mathrm{~m}$ around a prominent basement high, the Naudé Ridge (Dingle et al., 1987) (Figs. 4 and 5A). The continental slope of the central sector is dominated by along-slope sedimentary processes (Figs. 4 and 5B), except south of $27^{\circ} \mathrm{S}$, where the upper slope is dissected by several submarine canyons of varying size (from 50 - 300 m wide and 10 - 40 m deep to 750 - 2000 m wide and $>400 \mathrm{~m}$ deep) (Fig. 4). Evidence of down-slope sedimentary processes is common along the slope of the northern sector. Large Mass Transport Deposits (MTDs) appear in the middle to lower slope, where huge deposits gather on the seafloor (Fig. 4) or appear as buried features in seismic profiles (Fig. 5C). This sector also hosts many submarine canyon systems (SCSs). Wiles et al. (2017) identified three different SCSs of this area. From north to south, these include the Angoche SCS, the Middle Zambezi SCS, and the Lower Zambezi SCS (Fig. 4). In the Angoche SCS, the margin consists of a series of canyons that extend across the shelf towards the lower slope and from the shelf to the middle slope (Fig. 4). These canyons reach widths of up to $4 \mathrm{~km}$ (Fig. 5D). The Lower Zambezi SCS consists of canyons mostly initiating in the middle slope at around $1000 \mathrm{~m} \mathrm{wd}$. A few of these canyons appear at around $300 \mathrm{~m}$ wd. These canyons can reach $12 \mathrm{~km}$ in width (Fig. 5C). Along the abyssal plain, sedimentary lobes form at the distal limit of the lower slope of the Angoche SCS and the Lower Zambezi SCS (Figs. 4, 5C, and 5D). The Middle Zambezi SCS consists of canyons mostly initiating in the middle slope (Fig. 4). The present-day canyons lack any form of connection either with modern continental drainage channels or with incisional canyons on the shelf. These canyons reach widths of up to $7 \mathrm{~km}$ and incision depths of up to $200 \mathrm{~m}$ at around $2500 \mathrm{~m}$ wd. Along the abyssal plain, the Middle Zambezi SCS converges at about $19^{\circ}$ $S$ to join the Zambezi Valley. The combined feature then flows towards the south confined by the western flank of the Davie Fracture Zone (DFZ) until about $25^{\circ} \mathrm{S}$ where a large sedimentary lobe develops (Fig. 4).

\subsection{Contourite features}

Our analysis identified a wide range of contourite features, including depositional (drifts and sedimentary waves), erosional (abraded surfaces, moats, channels, scours, and furrows), and mixed (contourite terraces) features occurring from the shelf break to the abyssal plain (Fig. 4). Contourite drifts represent important along-slope accumulations of sediment that appear as continuous, layered seismic reflections with internal, regional-scale unconformities (Fig. 6). Erosional features are mainly characterized by truncated reflections underlying stratified and / or chaotic facies. These generally show relatively high amplitude reflections (HARs) relative to those representing associated drifts (Fig. 6). The mixed features 
252

(contourite terraces) display similar seismic facies defined by continuous to discontinuous, subparallel, and occasionally truncated seismic reflections (Fig. 6). High amplitude reflections are generally found along these terraces with a number of 2D sedimentary waves (e.g., Flemming, 1978; Green, 2011).

\subsubsection{Depositional contourite features}

Drifts are the dominant depositional features observed. The largest of these features are 'plastered drifts' and 'elongated-mounded drifts'. Large, plastered drifts of the Mozambique continental slope show a prominent along-slope trend (Fig. 4). Elongated-mounded drifts are dispersed throughout the continental slope and abyssal plain of Mozambique's central sector (Fig. 4). In addition to large-scale plastered and elongated-mounded drifts, other minor depositional features include large 'sedimentary waves' previously described by Breitzke et al. (2017). These exhibit a wavy geometry (Fig. 5B) and occur throughout the abyssal plain, particularly south of the Bassas Da India seamounts in the centre of the Mozambique Channel (Fig. 4).

The three plastered drifts recognized in this study were informally referred to as D1 to D3 based on their water depth range along the slope (D1 being the shallowest and D3 the deepest; Fig. 4). 'Plastered drifts 1 and 2' (D1 and D2) are located between $~ 300$ and $600 \mathrm{~m} \mathrm{wd}$ along the upper slope and between $\sim 900$ and $1300 \mathrm{~m}$ wd along the middle slope, respectively (Fig. 4). These show aggradational and progradational internal reflection configurations with thickness variations that indicate depocenters parallel to the slope (Figs. 5E, 6A, 6B, and 6I). In the southern sector, the $10-40 \mathrm{~km}$ wide D1 developed between $30^{\circ} \mathrm{S}$ and the Tugela Cone (Fig. 4). In the central sector, D1 spans about $20 \mathrm{~km}$ width and extends $\sim 56 \mathrm{~km}$ along the Inharrime Terrace (Fig. 4). In the northern sector, D1 is about $7 \mathrm{~km}$ wide and disappears near $18^{\circ} \mathrm{S}$ (Fig. 4). In the southern sector, the 15 $\mathrm{km}$ wide D2 developed between $30^{\circ} \mathrm{S}$ and the Tugela Cone (Fig. 4). In the central sector, between $29^{\circ} \mathrm{S}$ and $25^{\circ} \mathrm{S}$, D2 spans about $10 \mathrm{~km}$ in width (Fig. 4), and extends $\sim 116 \mathrm{~km}$ near $27^{\circ} \mathrm{S}$ before it disappears in the vicinity of topographic highs associated with the Almirante Leite Bank (Fig. 4). North of the Almirante Leite Bank, D2 is about 6 - $30 \mathrm{~km}$ wide and disappears in the vicinity of the southeastern limb of the Beira High, near the northern sector (Fig. 4). The deeper 'plastered drift 3' (D3) occurs in the lower slope of the central sector (between $\sim 27^{\circ} \mathrm{S}$ and $29^{\circ} \mathrm{S}$ ) at $\sim 1500-2200 \mathrm{~m}$ wd (Fig. 4). Between the Tugela Cone and the abraded surface, D3 extends to $88 \mathrm{~km}$ width (Fig. 4). In this area, D3 exhibits aggradational to progradational internal reflections with a more pronounced upslope progradational stacking pattern than those exhibited by drifts D1 and D2 
(Fig. 6C). North of the abraded surface, D3 extends to a width of about $110 \mathrm{~km}$ along the Central Terrace (Fig.

4) and exhibits predominantly progradational and seaward internal reflections (Fig. 6E). mounded drifts' (Fig. 4). Along the distal limit of the middle slope, elongated-mounded drifts occur east of the Almirante Leite Bank, near $24^{\circ} \mathrm{S}$ (Fig. 4), where they reach about $12 \mathrm{~km}$ in width (Fig. 6B). Along the lower slope, elongated-mounded drifts are widespread from $22^{\circ} \mathrm{S}$ to $26^{\circ} \mathrm{S}$, ranging $1-20 \mathrm{~km}$ in width (Fig. 4). From the distal limit of the lower slope to about $3200 \mathrm{~m}$ wd, elongated-mounded drifts occur in association with steep surfaces of the Mozambique Ridge $\left(29^{\circ} \mathrm{S}\right.$ to $\left.22^{\circ} \mathrm{S}\right)$ and the south-eastern limb of the Beira High $\left(21^{\circ} \mathrm{S}\right)$. These drifts reach widths of about 6 - 60 km (Figs. 4, 5B, 6F, and 6G). water depths of $\sim 3500$ to $4500 \mathrm{~m}$, sedimentary waves can reach $60-80 \mathrm{~m}$ in height and up to $5 \mathrm{~km}$ in length, with wavelengths around $2.5-3 \mathrm{~km}$. These features generally orient in a NE-SW direction, but then shift to WSW-ENE and WNW-ESE orientations to the north (Fig. 4). For water depths between $\sim 3000$ and $3400 \mathrm{~m}$, sedimentary waves reach heights of $35-60 \mathrm{~m}$, wavelengths around $1-2 \mathrm{~km}$, and lengths of up to $10 \mathrm{~km}$. These shallower features strike NW-SE, but shift into W-E and NE-SW orientations to the east (Fig. 4).

Erosive contourite features occur locally along the Mozambican continental margin and basin floor.

Erosional features include moats / contourite channels, abraded surfaces, and lineations (i.e., scours and furrows) (Fig. 4). 'Abraded surfaces' occur along the lower slope of the central sector (Figs. 4, 5B, 6B, 6G, and $6 \mathrm{H}$ ), and north of the Naudé Ridge ( $\sim 50 \mathrm{~km}$ wide, $\sim 100 \mathrm{~km}$ long, and deepening from $\sim 1900$ to $2300 \mathrm{~m} \mathrm{wd}$ ) (Figs. 4, and 6D). They also appear as steep surfaces related to the Mozambique Ridge ( $29^{\circ} \mathrm{S}$ to $22^{\circ} \mathrm{S}$ ) and the southeastern limb of the Beira High $\left(21^{\circ} \mathrm{S}\right)$ at the base of the slope (Figs. 4, 5B, 6G, and 6H). 'Moats' are associated with elongated-mounded drifts and exhibit U-shaped cross sections (Figs. 4, 5B, 6B, 6F, and 6G). in the vicinity of the large topographic highs of the Almirante Leite Bank and within the deeper corridor of the Mozambique Ridge (Fig. 4). 'Lineations' (i.e., scours and furrows) occur along the abyssal plain near $26^{\circ} \mathrm{S}$ (Fig. 
can reach $20 \mathrm{~km}$ in length, $3-7 \mathrm{~km}$ in width and incisional depths of up to $450 \mathrm{~m}$. Several large 'furrows' (i.e.,

$60-100 \mathrm{~m}$ deep, $2-3 \mathrm{~km}$ wide, and $8-15 \mathrm{~km}$ long) are located east of the giant erosional scours between

$3600-4300 \mathrm{~m}$ wd. Furrows generally assume a NW-SE or E-W orientation and a smooth V-shape morphology as described in Breitzke et al. (2017).

'Contourite terraces' represent mixed features that appear as sub-horizontal elements developed during longterm depositional and erosional phases of the continental slope (Hernández-Molina et al., 2016a). These form erosive features in proximal domains and mostly depositional features in distal domains. Terraces are morphological features that extend to distinct depth intervals above large plastered drifts to produce long flatter areas with subtle $\left(<1^{\circ}\right)$ seaward dips along the Mozambican margin (T1 to T4) (Figs. 5B, and 6). Terraces develop along the upper slope ( $\mathrm{T} 1 \mathrm{at} \sim 300 \mathrm{~m}$ wd) near the transition between upper and middle slopes ( $\mathrm{T} 2$ at $\sim 800 \mathrm{~m} \mathrm{wd}$ ), near the transition between middle and lower slopes ( $\mathrm{T} 3 \mathrm{at} \sim 1500 \mathrm{~m} \mathrm{wd}$ ), and along the lower slope (T4 at $\sim 2200 \mathrm{~m}$ wd) (Figs. 4, and 5B).

'Terrace 1 ' (T1) is associated with the upper surface and landward proximal domain of the D1 drift

(Fig. 6A). In the southern sector, $\mathrm{T} 1$ develops between $30^{\circ} \mathrm{S}$ and the Tugela Cone to reach a width of $\sim 4 \mathrm{~km}$. In the central sector, T1 reaches $\sim 4-5 \mathrm{~km}$ in width and extends $\sim 50 \mathrm{~km}$ along the Inharrime Terrace. In the northern sector, T1 reaches about $\sim 2.5 \mathrm{~km}$ in width and disappears near $18^{\circ} \mathrm{S}$ (Fig. 4). 'Terrace $2^{\prime}$ (T2) is associated with the top surface and landward proximal domain of the D2 drift (Fig. 6A). In the southern sector, $\mathrm{T} 2$ forms between $30^{\circ} \mathrm{S}$ and the Tugela Cone to reach widths of $\sim 15 \mathrm{~km}$. In the central sector between $29^{\circ}$ and $25^{\circ} \mathrm{S}$, T2 spans less than $1 \mathrm{~km}$ in width. It extends up to $\sim 30 \mathrm{~km}$ near $27^{\circ} \mathrm{S}$ (Limpopo Cone) before it disappears in the vicinity of the topographic highs of the Almirante Leite Bank. North of the Almirante Leite Bank, T2 reaches widths of about $\sim 20-30 \mathrm{~km}$ and extends $80 \mathrm{~km}$ near the Beira High. T2 disappears in the vicinity of the large MTDs occurring in the northern sector (Fig. 4). 'Terrace $3^{\prime}$ (T3) is associated with the top surface and landward proximal domain of the D3 drift (Figs. 6C, and 6E). In the central sector, T3 is about $\sim 4$ $25 \mathrm{~km}$ wide, extending $\sim 60 \mathrm{~km}$ and disappearing in the vicinity of the topographic highs of the Almirante Leite Bank. North of the Almirante Leite Bank, T3 is about 4 km wide but poorly developed relative to T1 and T2. 
333

appears from $21^{\circ}$ to $25^{\circ} \mathrm{S}$ where it spans about $\sim 60 \mathrm{~km}$ in width (Fig. $6 \mathrm{H}$ ). Toward the northern sector, T4 is about $\sim 2 \mathrm{~km}$ wide and disappears in the vicinity of the southeastern limb of the Beira High (21 S) (Fig. 4). Unlike T1-T3, which exhibit mostly a depositional character in their distal domain (i.e., plastered drifts D1 to D3), T4 exhibits a steep surface with an erosive character along its seaward flank (Figs. 4, and 6H).

\subsection{Identification of water masses and associated oceanographic processes}

Temperature and salinity profiles indicate seven major water masses operating the Mozambique Channel of the southwest Indian Ocean (Fig. 7 and table I). These include three of Indian origin (TSW, Tropical Surface Water; STSW, Subtropical Surface Water; and SICW, South Indian Central Water), one of North Atlantic origin (NADW, North Atlantic Deep Water), one of Red Sea origin (RSW, Red Sea Water), and two of Antarctic origin (AAIW, Antarctic Intermediate Water; AABW, Antarctic Bottom Water). An eighth water mass lies below the TSW, the Tropical Thermocline Water, which differs from STSW (same temperature) according to the former's much lower oxygen content (Lutjeharms, 2006) (Figs. 7D, and 7E). The TSW, STSW, Tropical Thermocline Water, and SICW make up the upper water column, while the AAIW and RSW constitute the intermediate water column, and the NADW and AABW form the base of the water column (Ullgren et al., 2012). Select neutral density profiles in this region showed that $\gamma^{\mathrm{n}}=\sim 26.4 \mathrm{~kg} / \mathrm{m}^{3}$ for the Subtropical Surface Water (STSW) - South Indian Central Water (SICW) transition, $\gamma^{\mathrm{n}}=27 \mathrm{~kg} / \mathrm{m}^{3}$ for the SICW - Antarctic Intermediate Water (AAIW) transition, $\gamma^{\mathrm{n}}=27.8 \mathrm{~kg} / \mathrm{m}^{3}$ for the AAIW - North Atlantic Deep Water (NADW), and $\gamma^{\mathrm{n}}=28.2 \mathrm{~kg} / \mathrm{m}^{3}$ for the NADW - Antarctic Bottom Water (AABW) (Toole and Warren, 1993; Talley, 1996; Ullgren et al., 2012) (Fig. 7). Identification of present water masses and their correlation with seafloor morphology can help elucidate longer-term oceanographic and sedimentary processes. The present oceanic circulation offshore of Mozambique is relatively complex and composed of various water masses interacting at different depths. These are briefly described below.

\subsubsection{Identification of water masses along the Southern Sector}

At shallow water depths $(<200 \mathrm{~m})$, the Tropical Surface Water (TSW; above $\left.24^{\circ} \mathrm{C}\right)$ covers the SubTropical Surface Water (STSW), which exhibits a maximum in salinity of 35.7 psu and temperature of around $17^{\circ} \mathrm{C}$ (Fig. 7A). Both are saturated in dissolved oxygen (Fig. 7D). Tropical Thermocline Water can be distinguished from STSW (same temperature) by the former's much lower dissolved oxygen concentrations $(<$ 
$4 \mathrm{ml} / \mathrm{l}$ ) (Fig. 7D). Directly below the STSW, within a neutral density range of $26.4 \mathrm{~kg} / \mathrm{m}^{3}$ to $26.8 \mathrm{~kg} / \mathrm{m}^{3}$ and a water depth range of about $200-600 \mathrm{~m}$, temperature-salinity properties declined down to values of $8-14^{\circ} \mathrm{C}$ and 34.8 - 35.5 psu, respectively. These parameters are characteristic of the South Indian Central Water (SICW) (Fig. 7A). The relatively fresh Antarctic Intermediate Water (AAIW) and relatively saline Red Sea Water (RSW) with neutral densities ranging from $27.0-27.8 \mathrm{~kg} / \mathrm{m}^{3}$ occupy intermediate depths below the thermocline (Fig. 7A). The AAIW forms a salinity minimum of $<34.5 \mathrm{psu}$, while the RSW modifies this minimum by interleaving the water column with relatively saline layers (> 34.6 psu) (Fig. 7A). Further downslope, at neutral densities greater than $27.8 \mathrm{~kg} / \mathrm{m}^{3}$, a cold $\left(\sim 2^{\circ} \mathrm{C}\right)$ and high salinity (> $\left.34.8 \mathrm{psu}\right)$ bottom layer is interpreted as the North Atlantic Deep Water (NADW) (Fig. 7A).

\subsubsection{Identification of water masses along the Central Sector}

Along this hydrographic section, the TSW, STSW, and Tropical Thermocline Water occupy the upper water column $\left(<200 \mathrm{~m}\right.$ wd, $\left.\gamma^{\mathrm{n}}<25.8 \mathrm{~kg} / \mathrm{m}^{3}\right)$ (Figs. 7B, and 7E). The TSW forms surface water, which is warmer than $24^{\circ} \mathrm{C}$. Directly beneath, the STSW exhibits a maximum in salinity of 35.8 psu at temperatures of around $17^{\circ} \mathrm{C}$ (Fig. 7B). TSW and STSW are saturated with dissolved oxygen while Tropical Thermocline Water, at the same depth as the STSW salinity maximum, exhibits lower dissolved oxygen concentrations $(<4 \mathrm{ml} / \mathrm{l})$ (Fig. 7E). At water depths of 200 to $600 \mathrm{~m}$, temperature-salinity properties ( $8-14^{\circ} \mathrm{C}$ and 34.8 to 35.5 psu, respectively) are characteristic of the SICW $\left(26.4 \mathrm{~kg} / \mathrm{m}^{3}\right.$ to $\left.26.8 \mathrm{~kg} / \mathrm{m}^{3}\right)$ (Fig. 7B). The AAIW appears at water depths of $\sim 800 \mathrm{~m}$ near the neutral density of the SICW-AAIW transition $\left(27 \mathrm{~kg} / \mathrm{m}^{3}\right)$ (Fig. 7B). The AAIW layer at this section exhibits low salinities ( 34.5). AAIW combines high salinities (> 34.6 psu) and low dissolved oxygen $(<3.5 \mathrm{ml} / \mathrm{I}$ ) layers of the RSW at water depths of 800 and $1500 \mathrm{~m}$ (Figs. 7B, and 7E). Below, as neutral densities surpass $27.8 \mathrm{~kg} / \mathrm{m}^{3}$, the NADW ( $<4^{\circ} \mathrm{C}, \sim 34.8 \mathrm{psu}$ ) appears at around $2200 \mathrm{~m}$ wd (Fig. 7B). At water depths around $3500-4000 \mathrm{~m}$, cold $\left(\sim 1.5^{\circ} \mathrm{C}\right)$, low salinity $(<34.7 \mathrm{psu})$ bottom waters approach the neutral density of the NADW-AABW transition $\left(28.2 \mathrm{~kg} / \mathrm{m}^{3}\right)$ (Fig. 7B).

\subsubsection{Identification of water masses along the Northern Sector}

The hydrographic section located in the northern part of the margin intersects the $2000 \mathrm{~m}$ isobath. Dissolved oxygen data for this part of the basin was not available. The surface water column is characterized by warm temperatures $\left(>24^{\circ} \mathrm{C}\right)$ and high salinity $(\sim 35.2 \mathrm{psu})$ of the TSW (Fig. 7C). Beneath this water mass lies 
the STSW, which exhibits a maximum salinity of $\sim 35.5 \mathrm{psu}$ and temperature of $15^{\circ} \mathrm{C}$ to give a neutral density of $<25.8 \mathrm{~kg} / \mathrm{m}^{3}$ for its upper layers $(<200 \mathrm{~m}$ wd) (Fig. 7C). Below the STSW salinity maximum, temperaturesalinity properties increase to values characteristic of the SICW, which exhibits a neutral density range of 26.4 $\mathrm{kg} / \mathrm{m}^{3}$ to $26.8 \mathrm{~kg} / \mathrm{m}^{3}$ in the $200-600 \mathrm{~m}$ depth range (Fig. $7 \mathrm{C}$ ). The base of the SICW reaches a local salinity minimum and neutral density of $27 \mathrm{~kg} / \mathrm{m}^{3}$, which marks the transition to properties associated with intermediate water masses (Fig. 7C). The intermediate water masses exhibit a neutral density range of 27 $\mathrm{kg} / \mathrm{m}^{3}$ to $27.8 \mathrm{~kg} / \mathrm{m}^{3}$ and flow at depths of 800 to $1500 \mathrm{~m}$ wd. The water masses are relatively salty and salinities greater than 34.9 psu in the middle of the density range indicate the presence of the RSW (Fig. 7C). Below the RSW, salinities decrease $(<34.7 \mathrm{psu})$ to another local minimum around $1500 \mathrm{~m}$ wd and $27.6 \mathrm{~kg} / \mathrm{m}^{3}$ density indicating a deeper AAIW core (Fig. 7C). For deeper water approaching $27.8 \mathrm{~kg} / \mathrm{m}^{3}$ neutral density, salinities increase to about $34.8 \mathrm{psu}$ at temperatures of around $2^{\circ} \mathrm{C}$. These parameters indicate the presence of the NADW in contact with the seafloor at around $2200 \mathrm{~m}$ wd (Fig. 7C).

\subsubsection{Associated interface processes}

Near-bottom layers for the water masses described above indicate that TSW, STSW and SICW traverse the continental shelf and upper slope of the Mozambican margin while the AAIW and RSW traverse the middle and lower slopes, and the NADW and AABW occupy the Mozambican base-of-slope and deep basins (Figs. 2, and 8). Interfaces between the TSW + STSW / SICW and SICW / AAIW (and RSW) thus interact with the Mozambican slope (Fig. 8), whereas interfaces between AAIW (and RSW) / NADW and NADW / AABW affect the Mozambican base-of-slope and basin floor. The interfaces (pycnoclines) between the TSW + STSW / SICW and SICW / AAIW are characterized by sharp density gradients while the interface between AAIW / NADW is characterized by a diffuse density gradient with a gradual transition from one water mass to the other (Fig. 9C). High values of buoyancy (Brunt-Väisälä) frequency ( $>2 \mathrm{cycl} / \mathrm{h}$ ) is observed at around $800 \mathrm{~m} \mathrm{wd}$ and above $\sim 300 \mathrm{~m}$ wd (Fig. 9A), matching the TSW + STSW / SICW and SICW / AAIW interfaces. Above $\sim 300 \mathrm{~m} w d$, the buoyancy (Brunt-Väisälä) frequency reaches maximum values around $50-100 \mathrm{~m}$ wd (> $6 \mathrm{cycl} / \mathrm{h}$ ) (Fig. 9B). Internal waves (solitons) were observed propagating from the shelf of the Bight of Sofala into the Indian Ocean $\left(20^{\circ} \mathrm{S}\right.$ to $21^{\circ} \mathrm{S}$; Figs. 10D, and 10E). Figs. 10 (A, B, and C) also illustrates internal wave propagation towards the coast in the Bay of Maputo. 
414

415

416

417

418

419

420

421

422

423

424

425

426

427

428

429

430

431

432

433

434

435

436

437

438

439

\subsection{Circulation model results}

Bottom current simulations carried out with the Regional Oceanic Modelling System (ROMS) indicated that currents often flow parallel to the isobaths but exhibit some degree of variation in direction and velocities depending on location (Fig. 11). Along the upper slope, the simulated bottom currents show southward movement with mean velocities of $>12.5 \mathrm{~cm} / \mathrm{s}$ (Figs. 11A, and 11B). The upper slope along the Inharrime Terrace and Limpopo Cone experienced W-NW transport near the shelf break (200 m wd) with inversions towards the W-SW, especially along the distal limit of the upper slope ( 1000 $\mathrm{m}$ wd) (Fig. 11C). Flow directions corresponded to a local cyclonic eddy previously described by Lamont et al. (2010). Along the middle slope, simulated bottom currents showed greater variability in current direction. Current direction was less rectilinear and flowed northward with at relatively low current velocities $(<12.5 \mathrm{~cm} / \mathrm{s})$. By contrast, current direction indicated southward transport deflected E-SE associated with the highest estimated current velocities (> 12.5 cm/s) (Figs. 11A, 11C, and 11D). Higher current speeds correspond to periods of southward moving anticyclonic eddies as documented by Schouten et al. (2003). Slope morphology constrains current direction near the Almirante Leite Bank. Steeper slope flanks in this area intensify circulation ( $>25 \mathrm{~cm} / \mathrm{s}$ ) (Fig. 11C). Along the lower slope, simulated currents showed predominantly northward transport with mean velocities reaching $>25 \mathrm{~cm} / \mathrm{s}$ (Fig. 11). Faster currents occur along steep surfaces around $1800 \mathrm{~m}$ (Fig. 11B), $2500 \mathrm{~m}$ (Fig. 11A) and $3000 \mathrm{~m}$ wd (Figs. 11D, and 11E) with mean velocities of $\sim 12.5 \mathrm{~cm} / \mathrm{s}$ but locally reaching as much $25 \mathrm{~cm} / \mathrm{s}$. Along the abyssal plain, simulated bottom currents intensify along the Mozambique Ridge with mean velocities oscillating between $12.5-25 \mathrm{~cm} / \mathrm{s}$ (Fig. 11D) and around Mt. Boucart, especially along its western flank, where mean velocities can exceed $25 \mathrm{~cm} / \mathrm{s}$ (Fig. 11B). Current directions indicate predominantly northward transport along the western side of the margin and eastward deflection in the middle of the abyssal plain (Figs. 11A, and 11E).

\section{Discussion}

The morpho-sedimentary map and oceanographic features described above enable interpretation of sedimentary processes operating within the Mozambique Channel. Interpretation indeed suggests that bottom currents adequately explain the formation and variability of observed contourite features (depositional, 
erosive and mixed). Matching contourite types with the relevant bottom water masses allows us to propose a

depositional model for the Mozambique Channel.

\subsection{Water-mass interfaces sculpt contourite terraces}

Contourite terraces 1 and 2 represent regional scale features formed along the Mozambique Channel while contourite terraces T3 and T4 show much more variation in their spatial distribution (Fig. 4). The terraces occur in water depths of $\sim 300 \mathrm{~m}$ for T1, $\sim 800 \mathrm{~m}$ for T2, 1500 m for T3 and $\sim 2200 \mathrm{~m}$ for T4. Hydrographic Sections A and B (Fig. 8) cover T1, T2, T3 and T4. These show that terraces occur close to the present water depth range of various water mass interfaces. For example, terrace T1 with Tropical + Subtropical Surface

Water (TSW + STSW) / South Indian Central Water (SICW) interface, terrace T2 with SICW / Antarctic Intermediate Water (AAIW) interface, and terraces T3 and T4 with AAIW / North Atlantic Deep Water (NADW) interface. The interfaces (pycnoclines) for T1 and T2 represent sharp and well-defined density gradients (Fig. 9C). A $700 \mathrm{~m}$ thick transition zone marks the interface for T3 and T4 between AAIW (800 - $1500 \mathrm{~m}$ wd) and NADW (2200 - $3500 \mathrm{~m} \mathrm{wd}$ ). The transition zone is marked by a diffuse density gradient with a gradual transition from one water mass to the other (Fig. 9C). These interfaces can be affected by different oceanographic processes, which are described below.

\subsubsection{The effect of internal tides}

According to both in situ measurements (tidal gauges) and numerical models, the most important harmonic affecting the Mozambique Channel is semi-diurnal $\left(M_{2}\right.$ tidal constituent; $\left.12.42 \mathrm{~h}\right)$ tides (sea-level amplitudes up to $2 \mathrm{~m}$ ) (Chevane et al., 2016). Manders et al. (2004) demonstrated that the barotropic tidal current (with the dominant $M_{2}$ component) velocity oscillates within $\pm 2-5 \mathrm{~cm} / \mathrm{s}$ in north-south direction. The east-west oriented tidal current oscillates within $\pm 1 \mathrm{~cm} / \mathrm{s}$ and is thus negligible, except along the shelf (30 - 70 $\mathrm{cm} / \mathrm{s}$; Chevane et al., 2016). Interaction between the barotropic tidal current with the bottom topography, in regions where it changes more or less abruptly, as ridges, banks, slopes, shelf breaks, etc., may often result in oscillates within $\pm 3-4 \mathrm{~cm} / \mathrm{s}$, with peaks exceeded $12 \mathrm{~cm} / \mathrm{s}\left(\sim 250 \mathrm{~m}\right.$ wd). Internal waves of tidal period $\left(\mathrm{M}_{2}\right)$ 
displacement $(\sim 100 \mathrm{~m})$ produced by internal waves propagation can be observed directly from Envisat advanced synthetic aperture radar (ASAR) images (Fig. 10). It shows clear evidence of internal waves travelling oceanward away from the shelf break (Figs. 10E, and 10D) and toward the continental shelf (Figs. 10A, 10B, and 10C). In Fig. 9, higher buoyancy (Brunt-Väisälä) frequency is observed on the proximal and / or nearly flat sector of terrace T1. It coincides with the water depth range of the interface between TSW + STSW / SICW ( $200 \mathrm{~m}$ wd). DaSilva et al. (2009) observed internal waves travelling at $1.4 \mathrm{~m} / \mathrm{s}$ with wavelengths of $0.5 \mathrm{~km}$ along the pycnocline near the surface $(\sim 60-100 \mathrm{~m})$. It leads to oscillation around $10 \mathrm{cycl} / \mathrm{h}$ which is consistent with values observed along T1 at $\sim 100 \mathrm{~m}$ wd (Fig. 9B). For T2, high values of buoyancy (Brunt-Väisälä) frequency along the water depth range of the interface between SICW / AAIW ( $800 \mathrm{~m}$ wd) (Fig. 9A) indicate a stably-stratified boundary layer, allowing for internal waves to propagate (Maas et al., 2018). Lastly, Maas et al. (2018) indicated that the fluctuation of the isopycnal (displacements of $80 \mathrm{~m}$ ) at 1500 wd was in general dominated by the internal tides, as reported for internal waves above. This fact point to a probable propagation of internal waves in the water depth range of T3. However, the study of Maas et al. (2018) is located along the narrowest part of the Mozambique Channel $\left(17^{\circ} \mathrm{S}\right)$ while T3 occurs at around $22^{\circ} \mathrm{S}$ (Fig. 4). This assumption remains nevertheless to be confirmed by further studies. Hence, we suggest that internal waves of tidal period may act as the primary mechanism in the erosion or non-deposition of contourite terraces T1, T2 and T3 as have been proposed along the south Atlantic continental slopes (e.g., HernándezMolina et al., 2009; Preu et al., 2013). These can mobilize and re-suspend bottom sediments (e.g., Cacchione et al., 2002; McCave, 2009; Pomar et al., 2012; Shanmugam, 2013).

\subsubsection{The effect of eddies}

Mesoscale eddies (either cyclonic or anticyclonic) can be considered as a further mechanism (e.g., García et al., 2015). Such eddies are well described along the Mozambique Channel (de Ruijter et al., 2002). $\sim 50-25 \mathrm{~cm} / \mathrm{s}$ at $\sim 200-300 \mathrm{~m}$ wd, respectively (Ternon et al., 2014). Current velocities are, however, greatly weakened near the bottom $(\sim 10 \mathrm{~cm} / \mathrm{s}$ at depths $>2000 \mathrm{~m})$ (Schouten et al., 2003). Consequently, these eddies were able to induce erosion or non-deposition along the contourite terraces. This finding is consistent 
495

496

497

498

499

500

501

502

503

504

505

506

507

508

509

510

511

512

513

514

515

516

517

518

519

520

521

waves are also likely to be amplified by interaction with mesoscale eddies (Magalhaes et al., 2014; Xie et al., 2015). Beal et al. (2006) also suggested eddy-induced generation of internal waves along the upper boundary of the NADW ( 2200 m wd) in the water depth range of T4 (e.g., Clément et al., 2017).

\subsubsection{The effect of along-slope bottom currents}

Another possible mechanism controlling sediment dynamics originates from the along-slope bottom currents. Fig. 11 shows clear evidence for high current velocities influencing T3 and T4 (>25 cm/s). For T3, Beal (2009) reported northward flow velocities of $25 \mathrm{~cm} / \mathrm{s}$ with peak speed over $95 \mathrm{~cm} / \mathrm{s}$ at $\sim 1400 \mathrm{~m}$ wd within the Agulhas undercurrent (1000 - $2900 \mathrm{~m}$ wd). Ridderinkhof and de Ruijter (2003) interpreted northward flow velocities of $4.5 \mathrm{~cm} / \mathrm{s}$ with peak speed around $40 \mathrm{~cm} / \mathrm{s}$ at $1500-2400 \mathrm{~m}$ wd within the Mozambique undercurrent. However, it should be noted that geostrophic flows have periods of intense, reduce or even revert circulation modulated by periodic or a-periodic processes (eddies, deep water tidal currents, etc.). Additionally, internal waves may be generated when the along-slope bottom currents flow over rough topography (Liang and Thurnherr 2012).

\subsection{Along-slope bottom current circulation governs the formation of plastered drifts}

Large-scale plastered drifts (D1 and D2) occur on a regional scale along the Mozambican margin while plastered drift D3 occurs on a more local scale (Fig. 4). These occur in basinward areas and in distal areas of contourite terraces $\mathrm{T} 1, \mathrm{~T} 2$ and $\mathrm{T} 3$, respectively (Figs. 6A, 6C, and 6E). Plastered drift water depths range from $\sim 300$ to $600 \mathrm{~m}$ for $\mathrm{D} 1, \sim 900$ to $1300 \mathrm{~m}$ for $\mathrm{D} 2$ and $\sim 1600$ to $\sim 2200 \mathrm{~m}$ for D3. Their distribution determines morphological seafloor changes that roughly coincide with the major physiographic provinces (D1, upper slope; D2, middle slope; and D3, lower slope; Figs. 5, and 6). Thus, these have significant effect in the shaping of the continental margin (e.g., Mosher et al., 2017). Hydrographic sections indicate that D1 and D2 match the near-bottom layer distribution of water masses bounded by the most pronounced density contrasts (pycnoclines) (Fig. 9). We therefore interpret large plastered drifts D1 and D2 along the Mozambican slope as influenced by the SICW (200 - $600 \mathrm{~m}$ wd) and AAIW (800 - $1500 \mathrm{~m}$ wd), respectively (Figs. 8A, and 8B). In contrast, plastered drift D3 occurs in the transition zone between AAIW (800 - $1500 \mathrm{~m}$ wd) and NADW (2200 $3500 \mathrm{~m} \mathrm{wd}$ ). Along-slope bottom currents move relatively slowly in the water depth range occupied by the plastered drifts ( $\sim 5-10 \mathrm{~cm} / \mathrm{s})$ (Fig. 11). These currents exhibit generally southward direction over D1 (Fig. 
11A), and northward direction over D2 and D3 (Figs. 11B, and 11D). This hypothesis is further confirmed by

523

524

525

526

527

528

529

530

531

532

533

534

535

536

537

538

539

540

541

542

543

544

545

546

547

548

other studies: Martin (1981) demonstrated that rapid sediment accumulation of D1 along the Inharrime Terrace occurs under weak southward flow conditions; and Beal (2009) reported weak northward flow velocities of $10 \mathrm{~cm} / \mathrm{s}$ at $1100 \mathrm{~m}$ wd in the water depth range of $D 2$.

These morpho-sedimentary and hydrographic coincidences lead us to propose that the regional physiographic configuration of the Mozambican margin is most likely related to along-slope bottom currents. Seismic profiles indicate that the present-day physiographic configuration and the sub-bottom architecture of the plastered drifts have a stable behaviour on geological timescales, as reported by Dingle et al. (1978) and Preu et al. (2011) for D1 along the Inharrime Terrace. It allows us to suggest a long-term, stable behaviour of the water masses (e.g., Rebesco et al., 2014; Ercilla et al., 2016). Thus, the observed variability of geostrophic flows in the region (eddies, deep water tidal currents, etc.) appears to have no significant effect in the longterm shaping of the continental margin. Although their apparent not significant effect may simply reflect poor interpretation because their importance cannot be resolved in our seismic profiles. This point was mentioned in the study of Ercilla et al. (2016). Lastly, the actual oceanographic model and all observed variability (eddies, deep water tidal currents, etc.) might differ over the geological time span of plastered drifts formation. This scenario might explain the present-day unusual location of D3 in the water depth range of the transition zone between two water masses (AAIW and NADW).

\subsection{Influence of bottom topography on bottom current processes}

The AAIW and NADW encounter obstacles such as seamounts (i.e., Almirante Leite Bank, Naudé Ridge), the Beira High and the Mozambique Ridge. These obstacles produce streamline distortions, creating current cores that can winnow, distribute, erode, and rework near-surface sediment (e.g., Kennett, 1982; Faugères et al., 1999; García et al., 2009). The AAIW and NADW usually have main current cores that run northward, parallel to isobaths along the walls of the obstacles (e.g., Dingle et al., 1987) (Fig. 11). The velocity of these cores manifests in erosive features (moats, contourite channels, abraded surfaces, and lineations; scours and furrows) (Fig. 4). Moats are associated with elongated-mounded drifts at the foot of high walls, as well as the abraded surfaces along their walls (e.g., Kennett, 1982; Hernández-Molina et al., 2006b) (Figs. 4, 5, and 6). These features suggest helicoidal flows around the cores of the current, referred to as 'horizontal 
eddies' (Rebesco et al., 2014). It result from Coriolis effect directing the cores of the current against the adjacent slope eroding the left side of the moat and depositing sediment on the right side where the current velocity is lower (e.g., Llave et al., 2001; Faugères and Mulder, 2011). The currents then form the abraded surfaces north of the Naudé Ridge (Fig. 6D) and along the steep lower-slopes of the Mozambique margin (Figs. 5B, 6G, and 6H). They also influence contourite channels and moats along the Almirante Leite Bank (Fig. 4), on the Mozambican lower-slope (Figs. 5B, and 6B), at the foot of the Mozambique Ridge (Figs. 5B, 6F, and 6G), and eastern-limb of the Beira High (Fig. 6G), and across deep, E-W corridors within the Mozambique Ridge (Fig. 4; described in Wiles et al., 2014). Finally, they form elongated-mounded drifts immediately seaward of moats (Figs. 5B, 6B, 6F, and 6G). As shown in Fig. 11, bands of high bottom current velocities (> $25 \mathrm{~cm} / \mathrm{s}$ ) correspond either to the presence of moats / contourite channels or abraded surfaces, while elongatedmounded drifts experience the lowest bottom current velocities $(<12.5 \mathrm{~cm} / \mathrm{s})$. Both are associated with northward flowing water masses of the AAIW and NADW within the Mozambique and Agulhas undercurrents. However, Fig. 11C shows the complexity of AAIW circulation, a large part of which is diverted southward. Observations of Dingle et al. (1978) and Martin (1981) support the interpretation given here by emphasizing that the deepest moats lie along upstream (NE) flanks of topographic highs centered on the Almirante Leite Bank between $\sim 900$ and $1300 \mathrm{~m}$ wd. This suggests southward flow of the AAIW following the model of Faugères et al. (1999), Llave et al. (2001), and Hernández-Molina et al. (2006b). Re-circulation of the AAIW may be due to the occurrence of passing moving anticyclonic eddies that also carry the RSW southward at a depth of 900 - 1200 m (Gründlingh, 1985; Ridderinkhof and de Ruijter, 2003). Beal (2009) also defined the core of the Agulhas undercurrent at $1000-2900 \mathrm{~m}$ wd, where it carries both AAIW and NADW northward. For the northern part of the Mozambique Channel near $17^{\circ} \mathrm{S}$, Ridderinkhof and de Ruijter (2003) interpreted the core of the Mozambique undercurrent at $1500-2400 \mathrm{~m}$ wd and suggested entrainment of the AAIW southward where it exits the local undercurrent. presence of the NADW, which would be locally guided by seafloor irregularities and incisions created by the Zambezi Valley and seamounts (i.e., Bassas Da India, Mt. Boucart) (Figs. 4, and 11). Breitzke et al. (2017) demonstrated that these sedimentary waves are draped with sediments, indicating that present-day velocities 
577 al. (2017) described bedforms as consisting mainly of large sedimentary waves, giant erosional scours, and

578 furrows. These occur in the transition zone $(\sim 500 \mathrm{~m})$ between the NADW $(<3500 \mathrm{~m})$ and the AABW ( $>4000$

$579 \mathrm{~m}$ ) and within the AABW. Crests tend to be aligned oblique to the current direction in the case of sedimentary

580 waves associated with geostrophic bottom currents (Fox et al., 1968; Manley and Flood, 1993). Simulation

581 results (Fig. 11E) demonstrate that bottom currents direction is consistent with the oblique alignments of the

582 sediment wave crests (Fig. 4). Here, the shallow bathymetry ( $<4000 \mathrm{~m} w \mathrm{~d}$ ) of the northern part of the margin topographically blocks the AABW to the north and deflects it eastward. Thus, we can infer that these features

584 likely result from the geostrophic flows $(\sim 12.5 \mathrm{~cm} / \mathrm{s})$, being aided by internal waves in the transition zone of NADW and AABW (3500 - $4000 \mathrm{~m}$ wd) (Kolla et al., 1980). Furrows, observed to run oblique relative to the main bottom currents, and scours point toward the northward flowing AABW (Figs. 4, and 11E). Furthermore, high northward flow velocities $\left(>25 \mathrm{~cm} / \mathrm{s}\right.$ ) at the foot of the Mozambique Ridge (along $37^{\circ} \mathrm{E}$, Fig. 11E) suggest the role of 'horizontal eddies' in generating these features (e.g., Hernández-Molina et al., 2014).

\subsection{A model for deep-sea sedimentation in the Mozambique Channel} rivers reach coastal areas, the Mozambique Current and Agulhas Current quickly disperse the suspended sediment over large areas along the continental shelf and upper slope. The Mozambique Undercurrent and Agulhas Undercurrent subsequently transport and deposit the sediment along the middle-lower slopes, baseof-slope, seamount flanks, and abyssal plain. The TSW + STSW (+ Tropical Thermocline Water) / SICW, SICW / AAIW (+ RSW), AAIW (+ RSW) / NADW, and NADW / AABW interfaces along the Mozambican margin form superimposed nepheloid layers by settling processes (McCave, 1986; Preu et al., 2013). For example, finegrained sediments arriving as turbidity currents from the continent are remobilized by the NADW / AABW interface and subsequently concentrated into a dense nepheloid layer between 3500 and 4500 m wd (Kolla et al., 1980). These layers represent a major regional / basin scale transport mechanism for fine-grained sediments at different water depths. They deposit sediments laterally and basinward with a dominant alongslope component. Material in the Mozambique Channel can thus experience significant transport over long distances prior to deposition. Turbulent processes generated at the interfaces (e.g., internal waves) interacting 
sediment (e.g., Dickson and McCave, 1986; Cacchione et al., 2002; Pomar et al., 2012; Shanmugam, 2013, feature along the water mass interface (Hernández-Molina et al., 2009; Preu et al., 2013). This sweep and winnow of the seafloor may also supply the nepheloid layers with sediment at the seaward limit of the terrace (Dickson and McCave, 1986; Puig et al., 2004; Wislon et al., 2015). Kolla et al. (1980) suggested that sedimentary waves on the Mozambican abyssal plain can result from very deep internal waves (e.g., van Haren and Gostiaux, 2011) focused on the nepheloid layer at the NADW / AABW interface between 3500 and $4500 \mathrm{~m}$ wd. Deposition occurs mainly in areas experiencing relatively low current velocities where settling of suspended particles can form contourite drifts (Miramontes et al., 2016; Cattaneo et al., 2017). Large-scale velocity variation in current pathways may reflect strong rotational current velocities $(>70 \mathrm{~cm} / \mathrm{s})$ due to southward moving anticyclonic eddies (Ridderinkhof and de Ruijter, 2003) interacting with the Mozambican margin morphology (Dingle et al., 1987). Contourite drifts can also form from local reworking of the seafloor by bottom currents (e.g., 'horizontal eddies'). In this case, topography influences the velocity of the impinging water-mass and sediments deposit near the eroded source area (Rebesco and Camerlenghi, 2008). Coriolis forcing of northward currents towards the Mozambican margin (e.g., Faugères and Mulder, 2011) can amplify this effect. In the depositional model for the Mozambique Channel described here, most present-day sedimentary processes and their morpho-sedimentary products result from bottom current processes. Observations from similar European and South American margins (Hernández-Molina et al., 2011, 2016a; Ercilla et al., 2016; Preu et al., 2013) support this interpretation. model in the future. First, we show a dominance of across-slope gravity-driven processes operating along the northern sector of the Mozambican margin (Fig. 4). Slope and shelf areas associated with the northern sector experienced high rates of sediment than those located in the central and southern sectors (e.g., estimated present annual sedimentary input: $100 \cdot 10^{6} \mathrm{t}$ from the Zambezi River; $4.8 \cdot 10^{6} \mathrm{t}$ from the Limpopo River, Milliman, 1981). In the northern sector, high rates of sediment delivery beginning in the Pliocene and continuing up to present (Dingle et al., 1983; Walford et al., 2005; Franke et al., 2015) may have conditioned large MTDs and maintained turbidity currents through time. In the central and southern sectors, limited 

reveals a combination of along-slope (i.e., T1 and D1) and across-slope (i.e., MTDs, turbidity currents) processes that may be related to sea-level fluctuations during glacial and inter-glacial periods (Wiles et al., 2017). During interglacial periods, sediments in front of the Zambezi River ('inner mud belt') are transported northward along the 'inner' shelf. Much of these sediments transfer through upper slope canyons of the Angoche SCS, few of these sediments are transported southward along the 'outer' shelf ('outer mud belt') toward the Middle and Lower Zambezi SCSs (Schulz et al., 2011; Wiles et al., 2017) (Fig. 4). This flux can be expected to have resulted in greater downslope transport (i.e., MTDs and turbidity currents) in front of the Angoche SCS than in front of the Middle and Lower Zambezi SCSs as it reached the shelf edge (Wiles et al., 2017) and may inhibit along-slope processes and their sedimentary features. Furthermore, shelf morphology (depth of the shelf-break, width of the shelf, etc.) during interglacial periods (such as in present-day, Wiles et al., 2017) is suitable for internal waves to propagate along the shelf edge, especially in front of the Middle and Lower Zambezi SCSs (DaSilva et al., 2009). Internal waves contributed to erosion, re-suspension, and redistribution of sediments along the upper slope, forming contourite terrace T1 and plastered drift D1 (e.g., Preu et al., 2013). During glacial periods, greater sediments supply and variation of the shelf morphology in front of the Middle and Lower Zambezi SCSs probably facilitate downslope sediment transport (Wiles et al., 2017) along the continental slope as well as preclude generation of internal waves. Further research can confirm or refute this hypothesis. transition zone between two water masses (AAIW and NADW) while upper plastered drifts (D2 and D3) match water depth ranges of water masses (SICW and AAIW) between density interfaces (pycnoclines) (e.g., Preu et al., 2013; Rebesco et al., 2014). However, the interpretation of D3 being generated in the transition zone between two water masses is questionable and it could be related to vertical movement of interfaces. The plastered drift formation is the result of processes acting on longer geological times. During the Quaternary, the Atlantic and Southwest Indian water-mass circulation and spatial fluctuations in water-mass interfaces may have been controlled by the Agulhas leakage (Hall et al., 2017) with less leakage during full glacial times than interglacial times (Peeters et al., 2004; Caley et al., 2012; Petrick et al., 2015). Variations of the Agulhas leakage 
661 (CDW and AABW) to extend farther north than it does today (Bickert and Wefer, 1996; Pena and Goldstein,

662 2014). During cold (glacial) periods under this scenario, the oceanographic setting would differ from the

663 present one and may have potentially provoked vertical and lateral variations of the interfaces and the associated oceanographic processes (e.g., internal waves), displacing drift D3 under the influence of deep Antarctic water masses. This interpretation is supported by Breitzke et al. (2017) suggesting that sedimentary waves under the water depth range of the NADW along the abyssal plain (Fig. 4) are draped with sediments. Thus, sedimentary waves might be related to strong bottom currents during cold periods, potentially under the AABW flow. While the discussion given above is somewhat speculative, and open a discussion proposed by Preu et al. (2013) in Argentine / Uruguay and Hernández-Molina et al. (2017b) in the Pacific margin of the Antarctic Peninsula about if some deep water features in the ocean are functional or relict. Are observed drifts and contourite terraces identify in deep-environments (lower slope and basin floor) relate to the same water masses structure than observed today? The conditions and timing of their formation, remain still unresolved but future research should address these questions.

\section{Conclusion}

This work interpreted a number of large contourite deposits along the Mozambique Channel and their associated bottom currents and oceanographic processes. The oceanographic processes described act in combination to determine the bottom current's local direction and velocity. Although many of these processes and their effects on deep-water sedimentation are not fully understood, local or regional interaction of these processes with the seafloor influences morphology and sediment distribution along the Mozambican continental margin and adjacent Durban basin. This study came to fourth major conclusions:

a) The first and most important finding is that internal waves originate from instabilities in the transition zone (interfaces / pycnoclines) between two water masses, caused by eddies, tidal and geostrophic currents being aided by topography. It provides the most plausible mechanism for sculpting contourite terraces (T1 to T4 in this study), facilitating erosion, re-suspension and redistribution of sediments (e.g., nepheloid layers).

b) Second, weak along-slope bottom currents on the plastered drifts (D1 to D3) rarely exceed 12.5 $\mathrm{cm} / \mathrm{s}$ and thus promote the settling of suspended particles. Growth of plastered drifts D1 and D2 
is facilitated by weak along-slope bottom currents of two major water-masses circulating in the Mozambique Channel (i.e., SICW and AAIW) or a counteraction of such currents with periodic or a-periodic processes (e.g., eddies, deep water tidal currents), reducing current velocities.

c) Third, the strengthening of along-slope bottom currents (e.g., Coriolis Effect, eddies, deep water tidal currents), being aided by seafloor irregularities would result in 'horizontal eddies'. Hence, these currents lead to erosion inside the moat and deposition on the elongated-mounded drift. Our study show that these drifts can develop inside the transition zone. Nevertheless, the finding in our study and limitations in the hydrodynamic modelling (e.g., secondary processes) point out a need for further studies, not only based on numerical simulations but also by field measurements (i.e., sedimentary cores and mooring scheme) to better quantify the impact of instabilities on contouritic depositional systems.

d) The fourth finding is that the specific plastered drift D3 in our study area occurs in the transition zone between two water masses (AAIW and NADW), and forms on a much smaller lateral scale. This marks a major difference between the plastered drift investigated here and the existing paradigm that plastered drifts are often formed below water mass interfaces (such as D1 and D2). A possible explanation for that could be related to the fact that, through geological times, vertical movements of water masses and associated interfaces occurred, as reported in the south Atlantic by Preu et al. (2013), where the AABW was thicker, more vigorous and its top quite shallower during glacial stages compared with interglacial stages, as the present one. This hypothesis highlight new and important considerations: are all present morphologies in deep marine environment functional? Can some depositional and erosional features, especially in the deepest oceans, be relicts, being active under different oceanographic processes than the present ones?

The Authors sincerely thank TOTAL S.A., WesternGeco, and CGG for permission in using seismic datasets. We also thank to the reviewers for their suggestions that helped us to improve the paper. The research formed part of Ph.D. thesis for A. Thiéblemont funded by TOTAL as part of the Frontier Exploration research program. 
Amante, C., Eakins, B.W., 2009. ETOPO1 1 Arc-Minute Global Relief Model: Procedures, Data Sources and Analysis. NOAA Technical Memorandum NESDIS NGDC-24, National Geophysical Data Center, NOAA. http://dx.doi.org/10.7289/V5C8276M

Beal, L.M., Ffield, A., Gordon, A.L., 2000. The spreading of Red Sea overflow waters in the Indian Ocean. Journal of Geophysical Research Oceans, 105, C4, 8549-8564. http://dx.doi.org/10.1029/1999JC900306

Beal, L.M., Chereskin, T.K., Lenn, Y.D., Elipot, S., 2006. The sources and mixing characteristics of the Agulhas Current. Journal of Physical Oceanography, 36, 11, 2060-2074. http://dx.doi.org/10.1175/JPO2964.1

Beal, L.M., 2009. A time series of Agulhas undercurrent transport. Journal of Physical Oceanography, 39, $2436-2450$. http://dx.doi.org/10.1175/2009JP04195.1

Bickert, T., Wefer, G., 1996. Late Quaternary Deep Water Circulation in the South Atlantic: Reconstruction from Carbonate Dissolution and Benthic Stable Isotopes, in: Wefer, G., Berger, W.H., Siedler, G., Webb, D.J. (Eds.), The South Atlantic: Present and Past Circulation. Springer-Verlag Berlin Heidelberg, 599-620. http://dx.doi.org/10.1007/978-3-642-80353-6 30

Breitzke, M., Wiles, E., Krocker, R., Watkeys, M.K., Jokat, W., 2017. Seafloor morphology in the Mozambique Channel: evidence for long-term persistent bottom-current flow and deep-reaching eddy activity. Marine Geophysical Research, 38, 3, 241-269. http://dx.doi.org/10.1007/s11001-017-9322-7

Broad, D.S., Jungslager, I.R., McLachlan, I.R., Roux, J., 2006. Offshore Mesozoic Basins, in: Johnson, M.R., Abhaeusser, C.R., Thomas, R.J. (Eds.), The Geology of South Africa. Geological Society of South Africa / Council for Geoscience, Johannesburg / Pretoria, 553-571.

Cacchione, D.A., Pratson, L.F., Ogston, A.S., 2002. The shaping of continental slopes by internal tides. Science, 296, 724-727. http://dx.doi.org/10.1126/science. 1069803

Caley, T., Giraudeau, J., Malaizé, B., Rossignol, L., Pierre, C., 2012. Agulhas leakage as a key process in the modes of Quaternary climate changes. Proceedings of the National Academy of Sciences of the United States of America, 109, 18, 6835-6839. http://dx.doi.org/10.1073/pnas.1115545109

Castelino, J., Reichert, C., Klingelhoefer, F., Aslanian, D., Jokat, W., 2015. Mesozoic and Early Cenozoic sediment influx and geomorphology of the Mozambique Basin. Marine and Petroleum Geology, 66, 890-905. http://dx.doi.org/10.1016/j.marpetgeo.2015.07.028

Cattaneo, A., Miramontes, E., Samalens, K., Garreau, P., Caillaud, M., Marsset, B., Corradi, N., Migeon, S., 2017. Contourite identification along Italian margins: The case of the Portofino drift (Ligurian Sea). Marine and Petroleum Geology, 87, 137147. $\mathrm{http}: / / \mathrm{dx}$.doi.org/10.1016/i-marpetgeo.2017.03.026

Chevane, C., Penven, P., Nehama, F., Reason, C., 2016. Modelling the tides and their impacts on the vertical stratification over the Sofala Bank, Mozambique. African Journal of Marine Sciences, 38, 4, 465-479. http://dx.doi.org/10.2989/1814232X.2016.1236039

Clément, L., Frajka-Williams, E., Sheen, K.L., Brearley, J.A., Naveira Garabato, A.C., 2017. Generation of internal waves by eddies impinging on the western boundary of the North Atlantic. Journal of Physical Oceanography, 46, 1067-1079. http://dx.doi.org/10.1175/JPO-D-14-0241.1

Coffin, M.F., Rabinowitz, P.D., 1987. Reconstruction of Madagascar and Africa: Evidence from the Davie Fracture Zone and Western Somali Basin. Journal of Geophysical Research, 92, B9, 9385-9406. http://dx.doi.org/10.1029/JB092iB09p09385

Coffin, M. F., Rabinowitz, P. D., 1992. The Mesozoic East African and Madagascan conjugate continental margins; stratigraphy and tectonics, in: Watkins, J.S., Zhigiang, F., McMillen, K.J. (Eds.), Geology and Geophysics of Continental Margins. AAPG Volume 53, 207-240. http://dx.doi.org/10.1306/M53552C12 
Courgeon, S., Jorry, S.J., Camoin, G.F., BouDagher-Fadel, M.K., Jouet, G., Révillon, S., Bachèlery, P., Pelleter, E., Borgomano, J., Poli, E., Droxler, A.W., 2016. Growth and demise of Cenozoic isolated carbonate platforms: New insights from the Mozambique Channel seamounts (SW Indian Ocean). Marine Geology, 380, 90-105. http://dx.doi.org/10.1016/i.margeo.2016.07.006

Creaser, A., Hernández-Molina, F.J., Badalini, G., Thompson, P., Walker, R., Soto, M., Conti, B., 2017. A Late Cretaceous mixed (turbidite-contourite) system along the Uruguayan Margin: Sedimentary and palaeoceanographic implications. Marine Geology, 390, 234-253. http://dx.doi.org/10.1016/i.margeo.2017.07.004

Da Silva, J.C.B., New, A.L., Magalhaes, J.M., 2009. Internal Solitary Waves in the Mozambique Channel: Observations and Interpretation. Journal of Geophysical Research Oceans, 114, C5. http://dx.doi.org/10.1029/2008JC005125

Davison, I., Steel, I., 2017. Geology and hydrocarbon potential of the East African continental margin: a review. Petroleum Geoscience, 24, 1. http://dx.doi.org/10.1144/petgeo2017-028

Debreu, L., Marchesiello, P., Penven, P., Cambon, G., 2012. Two-way nesting in split-explicit ocean models: algorithms, implementation and validation. Ocean Model, 49-50, 1-21. http://dx.doi.org/10.1016/i.ocemod.2012.03.003

Dee, D., Uppala, S., Simmons, A., Berrisford, P., Poli, P., Kobayashi, S., Vitart, F., 2011. The ERA-Interim reanalysis: Configuration and performance of the data assimilation system. Quarterly Journal of the Royal Meteorological Society, 137, 553-597. http://dx.doi.org/10.1002/qj.828

De Ruijter, W.P.M., Ridderinkhof, H., Lutjeharms, J.R.E., Schouten, M.W., Veth, C., 2002. Observations of the flow in the Mozambique Channel. Geophysical Research Letters, 29, 10, 140-1 - 140-3. http://dx.doi.org/10.1029/2001GL013714

Dickson, R., McCave, I.N., 1986. Nepheloid layers on the continental slope west of Porcupine Bank. Deep Sea Research Part A. Oceanographic Research Papers, 33, 6, 791-818. http://dx.doi.org/10.1016/0198-0149(86)90089-0

DiMarco, S.F., Chapman, P., Nowlin Jr., W.D., Hacker, P., Donohue, K., Luther, M., Johnson, G.C., Toole, J., 2002. Volume transport and property distributions of the Mozambique Channel. Deep-Sea Research Part II: Topical Studies in Oceanography, 49, 7-8, 1481-1511. http://dx.doi.org/10.1016/S0967-0645(01)00159-X

Dingle, R.V., Goodlad, S.W., Martin, A.K., 1978. Bathymetry and stratigraphy of the northern Natal Valley (SW Indian Ocean): a preliminary account. Marine Geology, 20, 89-106. http://dx.doi.org/10.1016/0025-3227(78)90099-3

Dingle, R.V., Siesser, W.G., Newton, A.R., 1983. Mesozoic and Tertiary Geology of Southern Africa: A Global Approach to Geology. A.A.Balkema, Rotterdam, 375. ISBN: 9789061910992

Dingle, R.V., Birch, G.F., Bremner, J.M., De Decker, R.H., Du Plessis, A., Engelbrecht, J.C., Fincham, M.J., Fitton, T., Flemming, B.W., Goodlad, S.W., Gentle, R.I., Martin, A.K., Mills, E.G., Moir, G.J., Parker, R.J., Robson, S.H., Rogers, J., Salmon, D.A., Siesser, W.G., Simpson, E.S.W., Summerhayes, C.P., Westall, F., Winter, A., Woodborne, M.W., 1987. Deep-sea sedimentary environments around southern Africa (SE-Atlantic \& SW-Indian Oceans). Annals South African Museum, 98, 1-27.

Donohue, K.A., Beal, L.M., Firing, E., 2000. Comparison of three velocity sections of the Agulhas Current and Agulhas Undercurrent. Journal of Geophysical Research, 105, C12, 28585-28593. http://dx.doi.org/10.1029/1999JC000201

Eagles, G., König, M., 2008. A model of plate kinematics in Gondwana breakup. Geophysical Journal International, 173, 2, 703-717. http://dx.doi.org/10.1111/j.1365-246X.2008.03753.x

Ercilla, G., Juan, C., Hernández-Molina, F.J., Bruno, M., Estrada, F., Alonso, B., Casas, D., Farran, M., Llave, E., García, M., Vázquez, J.T., D'Acremont, E., Gorini, C., Palomino, D., Valencia, El Moumni, B., Ammar, A., 2016. Significance of bottom currents in deep-sea morphodynamics: An example from the Alboran Sea. Marine Geology, 378, $157-170$. http://dx.doi.org/10.1016/i.margeo.2015.09.007

Fairall, C.W., Bradley, E.F., Rogers, D.P., Edson, J.B., Young, G.S., 1996. Bulk parameterization of air-sea fluxes for tropical ocean-global atmosphere coupled-ocean atmosphere response experiment. Journal of Geophysical Research, 101, C2, 3747-3764. http://dx.doi.org/10.1029/95JC03205

Faugères, J.-C., Stow, D.A.V., Imbert, P., Viana, A.R., 1999. Seismic features diagnostic of contourite drifts. Marine Geology, 162, 1-38. http://dx.doi.org/10.1016/S0025-3227(99)00068-7 
Faugères, J.-C., Stow, D.A.V., 2008. Chapter 14 Contourite Drifts: Nature, Evolution and Controls, in: Rebesco, M., Camerlenghi, A. (Eds.), Contourites. Developments in Sedimentology, Elsevier Science, Amsterdam, 60, 257-288. http://dx.doi.org/10.1016/S0070-4571(08)10014-0

Faugères, J. C., Mulder, T., 2011. Chapter 3 - Contour currents and contourite drifts, in: Hüneke, H., and Mulder, T. (Eds.), Deep-Sea Sediments. Elsevier, 63, 149-214. http://dx.doi.org/10.1016/B978-0-444-53000-4.00003-2

Ferry, N., Parent, L., Garric, G., Bricaud, C., Testut, C., LeGalloudec, O., Zawadzki, L., 2012. Glorys2v1 global ocean reanalysis of the altimetric era (1992-2009) at meso-scale. Mercator Ocean-Quaterly Newsletter, 44, 29-39.

Fine, R.A., 1993. Circulation of Antarctic Intermediate Water in the South Indian Ocean. Deep-Sea Research Part 1: Oceanographic Research Papers, 40, 10, 2021-2042. http://dx.doi.org/10.1016/0967-0637(93)90043-3

Fischer, M.D., Uenzelmann-Neben, G., Jacques, G., Werner, R., 2017. The Mozambique Ridge: a document of massive multistage magmatism. Geophysical Journal International, 208, 1, 449-467. http://dx.doi.org/10.1093/gji/ggw403

Flemming, B.W., 1978. Underwater sand dunes along the southeast African continental margin-observations and implications. Marine Geology, 26, 3-4, 177-198. http://dx.doi.org/10.1016/0025-3227(78)90059-2

Fox, P.J., Heezen, B.C. and Harian, A.M., 1968. Abyssal antidunes. Nature, 220, 470-472.

Franke, D., Jokat, W., Ladage, S., Stollhofen, H., Klimke, J., Lutz, R., Mahanjane, E.S., Ehrhardt, A., Schreckenberger, B., 2015. The offshore East African Rift System: Structural framework at the toe of a juvenile rift. Tectonics, 34, 10, $2086-2104$. http://dx.doi.org/10.1002/2015TC003922

García, M., Hernández-Molina, F.J., Llave, E., Stow, D.A.V., León, R., Fernández-Puga, M.C., Díaz del Río, V., Somoz, L., 2009. Contourite erosive features caused by the Mediterranean Outflow Water in the Gulf of Cadiz: Quaternary tectonic and oceanographic implications. Marine Geology, 257, 1-4, 24-40. http://dx.doi.org/10.1016/j.margeo.2008.10.009

García, M., Hernández-Molina, F.J., Alonso, B., Vázquez, J.T., Ercilla, G., Llave, E., Casas, D., 2015. Erosive sub-circular depression on the Guadalquivir Bank (Gulf of Cadiz): interaction between bottom current, mass wasting and tectonic processes. Marine Geology. http://dx.doi.org/10.1016/i.margeo.2015.10.004

Goodlad, S.W., Martin, A.K., Hartnady, C.J.H., 1982. Mesozoic magnetic anomalies in the southern Natal Valley. Nature, 295, 686-688. http://dx.doi.org/10.1038/295686a0

Gradstein, F.M., Ogg, J.G., Schmitz, M.D., Ogg, G.M., 2012. The geologic time scale 2012. Elsevier, 1176. ISBN: 9780444594488

Green, A.N., Ovechkina, M., Uken, R., 2008. Nannofossil age constraints on shelf edge wedge development: implications for continental margin dynamics, northern KwaZulu-Natal, South Africa. Continental Shelf Research, 28, 2442-2449. http://dx.doi.org/10.1016/j.csr.2008.06.007

Green, A., 2011. Submarine canyons associated with alternating sediment starvation and shelf-edge wedge development: Northern KwaZulu-Natal continental margin, South Africa. Marine Geology, 284, 114-126. http://dx.doi.org/10.1016/i.margeo.2011.03.011

Gruetzner, J., Uenzelmann-neben, G., 2015. Contourite drifts as indicators of Cenozoic bottom water intensity in the eastern Agulhas Ridge area, South Atlantic. Marine Geology, 378, 350-360. http://dx.doi.org/10.1016/i.margeo.2015.12.003

Gründlingh, M.L., 1985. Occurrence of Red Sea Water in the Southwestern Indian Ocean, 1981. Journal of Physical Oceanography, 15, 207-212. http://dx.doi.org/10.1175/1520-0485(1985)015<0207:OORSWI>2.0.CO;2

Hall, I.R., Hemming, S.R., LeVay, L.J., Barker, S., Berke, M.A., Brentegani, L., Caley, T., Cartagena-Sierra, A., Charles, C.D., Coenen, J.J., Crespin, J.G., Franzese, A.M., Gruetzner, J., Han, X., Hines, S.K.V., Jimenez Espejo, F.J., Just, J., Koutsodendris, A., Kubota, K., Lathika, N., Norris, R.D., Periera dos Santos, T., Robinson, R., Rolinson, J.M., Simon, M.H., Tangunan, D., van der Lubbe, J.J.L., Yamane, M., and Zhang, H., 2017. Site U1478, in: Hall, I.R., Hemming, S.R., LeVay, L.J., and the Expedition 361 Scientists, South African Climates (Agulhas LGM Density Profile). Proceedings of the International Ocean Discovery Program, 361: College Station, TX (International Ocean Discovery Program). http://dx.doi.org/10.14379/iodp.proc.361.107.2017 
Halo, I., Backeberg, B., Penven, P., Ansorge, I., Reason, C., Ullgren, J.E., 2014. Eddy properties in the Mozambique Channel: A comparison between observations and two numerical ocean circulation models. Deep Sea Research Part II: Topical Studies in Oceanography, 100, 38-53. http://dx.doi.org/10.1016/i.dsr2.2013.10.015

Hernández-Molina, F.J., Llave, E., Stow, D.A.V., García, M., Somoza, L., Vázquez, J.T., Lobo, F., Maestro, A., Díaz del Río, V., León, R., Medialdea, T., Gardner, J., 2006a. The contourite depositional system of the Gulf of Cadiz: a sedimentary model related to the bottom current activity of the Mediterranean outflow water and the continental margin characteristics. Deep Sea Research Part II: Topical Studies in Oceanography, 53, 11-13, 1420-1463. http://dx.doi.org/10.1016/j.dsr2.2006.04.016

Hernández-Molina, F.J., Larter, R.D., Rebesco, M., Maldonado, A., 2006b. Miocene reversal of bottom water flow along the Pacific Margin of the Antarctic Peninsula: Stratigraphic evidence from a contourite sedimentary tail. Marine Geology, 228, 93-116. http://dx.doi.org/10.1016/i.margeo.2005.12.010

Hernández-Molina, F.J., Paterlini, M., Violante, R., Marshall, P., de Isasi, M., Somoza, L., Rebesco, M., 2009. Contourite depositional system on the Argentine slope: an exceptional record of the influence of Antarctic water masses. Geology, 37, 6, 507-510. http://dx.doi.org/10.1130/G25578A.1

Hernández-Molina, F.J., Serra, N., Stow, D.A.V., Llave, E., Ercilla, G., Van Rooij, D., 2011. Along-slope oceanographic processes and sedimentary products around the Iberian margin. Geo-Marine Letters, 31, 5-6, 315-341. http://dx.doi.org/10.1007/s00367-011-0242-2

Hernández-Molina, F.J., Llave, E., Preu, B., Ercilla, G., Fontan, A., Bruno, M., Serra, N., Gomiz, J.J., Brackenridge, R.E., Sierro, F.J., Stow, D.A.V., García, M., Juan, C., Sandoval, N., Arnaiz, A., 2014. Contourite processes associated to the Mediterranean outflow water after its exit from the Gibraltar Strait: global and conceptual implications. Geology, 42, 3, $227-230$. http://dx.doi.org/10.1130/G35083.1

Hernández-Molina, F.J., Soto, M., Piola, A.R., Tomasini, J., Preu, B., Thompson, P., De Santa Ana, H., 2016a. A contourite depositional system along the Uruguayan continental margin: sedimentary, oceanographic and paleoceanographic implications. Marine Geology, 378, 333-349. http://dx.doi.org/10.1016/j.margeo.2015.10.008

Hernández-Molina, F.J., Wåhlin, A., Bruno, M., Ercilla, G., Llave, E., Serra, N., Roson, G., Puig, P., Rebesco, M., Van Rooij, D., Roque, C., González-Pola, C., Sánchez, F., Gómez, M., Preu, B., Schwenk, T., Hanebuth, T.J.J., Sánchez-Leal, R.F., García Lafuente, J., Brackenridge, R.E., Juan, C., Stow, D.A.V., Sánchez-González, J.M., 2016b. Oceanographic processes and products around the Iberian margin: a new multidisciplinary approach. Marine Geology, Special Issue: The Contourite LogBook 378, 127-156. http://dx.doi.org/10.1016/j.margeo.2015.12.008

Hernández-Molina, F.J., Campbell, S., Badalini, G., Thompson, P., Walker, R., Soto, M., Conti, B., Preu, B., Thieblemont, A., Hyslop, L., Miramontes, E., Morales, E., 2017a. Large bedforms on contourite terraces: Sedimentary and conceptual implications. Geology, 46, 27-30. http://dx.doi.org/10.1130/G39655.1

Hernández-Molina, F.J., Larter, R.D., Maldonado, A., 2017b. Neogene to Quaternary stratigraphic evolution of the Antarctic Peninsula, Pacific Margin offshore of Adelaide Island: Transitions from a non-glacial, through glacially-influenced to a fully glacial state. Global and Planetary Change, 156, 80-111. http://dx.doi.org/10.1016/i.gloplacha.2017.07.002

Hicks, N., Green, A., 2016. Sedimentology and depositional architecture of a submarine delta-fan complex in the Durban Basin, South Africa. Marine and Petroleum Geology, 78, 390-404. http://dx.doi.org/10.1016/j.marpetgeo.2016.09.032

IHO., IOC., 1983. Standardization of undersea feature names: guidelines, proposal form, terminology. International Hydrographic Bureau, Monaco. 27p.

Jackson, C.R., 2004. An Atlas of Internal Solitary-like Waves and their Properties. Global Ocean Associates, Rockville, MD (prepared for Office of Naval Research). [Online-27/02/2018] http://www.internalwaveatlas.com

Jokat, W., Boebel, T., König, M., Meyer, U., 2003. Timing and geometry of early Gondwana breakup. Journal of Geophysical Research, 108, B9. http://dx.doi.org/10.1029/2002JB001802

Kennett, J., 1982. Marine Geology. Prentice Hall, 813. ISBN: 9780135569368

Kolla, V., Eittreim, S., Sullivan, L., Kostecki, J.A., Burckle, L.H., 1980. Current-controlled, abyssal microtopography and sedimentation in Mozambique Basin, Southwest Indian Ocean. Marine Geology, 34, 3-4, 171-206. http://dx.doi.org/10.1016/0025-3227(80)90071-7 
König, M., Jokat, W., 2010. Advanced insights into magmatism and volcanism of the Mozambique Ridge and Mozambique Basin in the view of new potential field data. Geophysical Journal International, 180, 1, $158-180$. http://dx.doi.org/10.1111/j.1365-246X.2009.04433.x

Lamont, T., Roberts, M.J., Barlow, R.G., Morris, T., van den Berg, M.A., 2010. Circulation patterns in the Delagoa Bight, Mozambique, and the influence of Deep Ocean eddies. African Journal of Marine Science, 32, 3, 553-562. http://dx.doi.org/10.2989/1814232X.2010.538147

Leinweber, V.T., Jokat, W., 2012. The Jurassic history of the Africa-Antarctica Corridor - new constraints from magnetic data on the conjugate continental margins. Tectonophysics, 530-531, 87-101. http://dx.doi.org/10.1016/i.tecto.2011.11.008

Leinweber, V.T., Klingelhoefer, F., Neben, S., Reichert, C., Aslanian, D., Matias, L., Heyde, I., Schreckenberger, B., Jokat, W., 2013. The crustal structure of the Central Mozambique continental margin d Wide-angle seismic, gravity and magnetic study in the Mozambique Channel, Eastern Africa. Tectonophysics, 599, 170-196. http://dx.doi.org/10.1016/j.tecto.2013.04.015

Liang, X., Thurnherr, A.M., 2012. Eddy-modulated internal waves and mixing on a midocean ridge. Journal of Physical Oceanography, 42, 1242-1248. http://dx.doi.org/10.1175/JPO-D-11-0126.1

Llave, E., Hernández-Molina, F.J., Somoza, L., Díaz del Río, V., Stow, DAV., Maestro, A., Alveirinho Dias, J.M., 2001. Seismic stacking pattern of the Faro-Albufeira contourite system (Gulf of Cadiz): a Quaternary record of paleoceanographic and tectonic influences. Marine Geophysical Research, 22, 5-6, 487-508. http://dx.doi.org/10.1023/A:1016355801344

Lutjeharms, J.R.E., 2006. The Agulhas Current. Springer-Verlag Berlin Heidelberg, 329. ISBN: 978-3-540-37212-7

Maas, L.R.M., Aguiar-González, B., Ponsoni, L., 2018. Deep-Ocean Tides in the South-West Indian Ocean: Comparing DeepSea Pressure to Satellite Data, in: Velarde, M., Tarakanov, R., Marchenko, A. (Eds.), The Ocean in Motion. Springer Oceanography. Springer, pp 147-182. http://dx.doi.org/10.1007/978-3-319-71934-4 12

Magalhaes, J.M., da Silva, J.C.B., New, A.L., 2014. Internal Solitary Waves System in the Mozambique Channel, in: Barale, V., Gade, M. (Eds.), Remote Sensing of the African Seas. Springer, Dordrecht, pp 263-284. http://dx.doi.org/10.1007/97894-017-8008-7 14

Manders, A.M.M., Maas, L.R.M., Gerkema, T., 2004. Observations of internal tides in the Mozambique Channel. Journal of Geophysical Research, 109, C12. http://dx.doi.org/10.1029/2003JC002187

Manley, P.L., Flood, R.D., 1993. Project MUDWAVES. Deep Sea Research II, 40, 851-857. http://dx.doi.org/10.1016/09670645(93)90037-N

Martin, A.K., 1981. The influence of the Agulhas Current on the physiographic development of the northernmost Natal Valley (S.W. Indian Ocean). Marine Geology, 39, 3-4, 259-276. http://dx.doi.org/10.1016/0025-3227(81)90075-x

McCave, I.N., Tucholke, B.E., 1986. Deep current controlled sedimentation in the western North Atlantic, in: Vogt, P.R., Tucholke, B.E. (Eds.), The Western North Atlantic Region. Geology of North America, Volume M. 451-468. http://dx.doi.org/10.1130/DNAG-GNA-M.451

McCave, I.N., 2009. Nepheloid Layers, in: Steele, J.H., Thorpe, S.A., Turekian, K.K. (Eds.), Encyclopedia of Ocean Sciences (Second Edition). Academic Press, London, 8-18. ISBN: 978-0-12-374473-9. http://dx.doi.org/10.1016/B978-012374473$\underline{9.00671-8}$

McElhinny, M.W., 1970. Formation of the Indian Ocean. Nature, 228, 977-979. http://dx.doi.org/10.1038/228977a0

McKenzie, D., Sclater, J.G., 1971. The evolution of the Indian Ocean since the Late Cretaceous. Geophysical Journal International, 24, 5, 437-528. http://dx.doi.org/10.1111/j.1365-246X.1971.tb02190.x

Milliman, J.D., 1981. Transfer of river-borne material to the oceans, in: Martin, J.M., Burton, J.D., Eisma, D. (Eds.), River inputs to ocean systems. UNESCO, Paris, 5-12.

Miramontes, E., Cattaneo, A., Jouet, G., Thereau, E., Thomas, Y., Rovere, M., Cauquil, E., Trincardi, F., 2016. The pianosa contourite depositional system (northern Tyrrhenian Sea): drift morphology and plio-quaternary stratigraphic evolution. Marine Geology, 378, 20-42. http://dx.doi.org/10.1016/j.margeo.2015.11.004 
Mosher, D.C., Campbell, D.C., Gardner, J.V., Piper, J.W., Chavtor, J.D., Rebesco, M., 2017. The role of deep-water sedimentary processes in shaping a continental margin: The Northwest Atlantic. Marine Geology, 393, $245-259$. http://dx.doi.org/10.1016/j.margeo.2017.08.018

Mougenot, D., Recq, M., Virlogeux, P., Lepvrier, C., 1986. Seaward extension of the East African Rift. Nature, 321, 599-603. http://dx.doi.org/10.1038/321599a0

Niemi, T.M., Ben-avraham, Z., Hartnady, C.J.H., Reznikov, M., 2000. Post-Eocene seismic stratigraphy of the deep ocean basin adjacent to the southeast African continental margin: a record of geostrophic bottom current systems. Marine Geology, 162, 2-4, 237-258. http://dx.doi.org/10.1016/S0025-3227(99)00062-6

Orsia, A.H., Johnsonb, G.C., Bullisterb, J.L., 1999. Circulation, mixing, and production of Antarctic Bottom Water. Progress in Oceanography, 43, 1, 55-109. http://dx.doi.org/10.1016/S0079-6611(99)00004-X

Peeters, F.J.C., Acheson, R., Brummer, G.J.A., de Ruijter, W.P.M., Schneider, R.R., Ganssen, G.M., Ufkes, E., Kroon, D., 2004. Vigorous exchange between the Indian and Atlantic Oceans at the end of the past five glacial periods. Nature, 430, 7000, 661-665. http://dx.doi.org/10.1038/nature02785

Pena, L.D., Goldstein, S.L., 2014. Thermohaline circulation crisis and impacts during the mid-Pleistocene transition. Science, 345, 6194, 318-322. http://dx.doi.org/10.1126/science.1249770

Petrick, B.F., McClymont, E.L., Marret, F., van der Meer, M.T.J., 2015. Changing surface water conditions for the last 500 ka in the southeast Atlantic: implications for variable influences of Agulhas leakage and Benguela upwelling. Paleoceanography, 30, 9, 1153-1167. http://dx.doi.org/10.1002/2015PA002787

Pomar, L., Morsilli, M., Hallock, P., Bádenas, B., 2012. Internal waves, an underexplored source of turbulence events in the sedimentary record. Earth Science Reviews, 111, 1-2, 56-81. http://dx.doi.org/10.1016/i.earscirev.2011.12.005

Preu, B., Spieß, V., Schwenk, T., Schneider, R., 2011. Evidence for current-controlled sedimentation along the southern Mozambique continental margin since Early Miocene times. Geo-Marine Letters, 31, 5-6, 427-435. http://dx.doi.org/10.1007/s00367-011-0238-y

Preu, B., Hernández-Molina, F.J., Violante, R., Piola, A.R., Paterlini, C.M., Schwenk, T., Spiess, V., 2013. Morphosedimentary and hydrographic features of the northern Argentine margin: the interplay between erosive, depositional and gravitational processes and its conceptual implications. Deep-Sea Research Part I: Oceanography Research Papers, 75, 157-174. http://dx.doi.org/10.1016/j.dsr.2012.12.013

Puig, P., Palanques, A., Guillén, J., El Khatab, M., 2004. Role of internal waves in the generation of nepheloid layers on the northwestern Alboran slope: implications for continental margin shaping. Journal of Geophysical Research Oceans, 109, C9. http://dx.doi.org/10.1029/2004JC002394

Read, J.F., Pollard, R.T., 1999. Deep inflow into the Mozambique Basin. Journal of Geophysical Research Oceans, 104, C2, 3075-3090. http://dx.doi.org/10.1029/1998JC900078

Rebesco, M., Stow, D., 2001. Seismic expression of contourites and related deposits: a preface. Marine Geophysical Research, 22, 5-6, 303-308. http://dx.doi.org/10.1023/A:1016316913639

Rebesco, M., 2005. Contourites, in: Selley, R.C., Cocks, L.R.M., Plimer, I.R. (Eds.), Encyclopedia of Geology. Oxford: Elsevier, 513-527. ISBN: 978-0-12-369396-9

Rebesco, M., Camerlenghi, A., 2008. Contourites. Developments in Sedimentology, Elsevier Science, Amsterdam, 60, 688. ISBN: 978-0-444-52998-5

Rebesco, M., Hernández-Molina, F.J., van Rooij, D., Wåhlin, A., 2014. Contourites and associated sediments controlled by deep-water circulation processes: state-of-the-art and future considerations. Marine Geology, 352, 111-154. http://dx.doi.org/10.1016/j.margeo.2014.03.011

Ridderinkhof, H., de Ruijter, W.P.M., 2003. Moored current observations in the Mozambique Channel. Deep-Sea Research Part II: Topical Studies in Oceanography, 50, 12-13, 1933-1955. http://dx.doi.org/10.1016/S0967-0645(03)00041-9

Said, A., Moder, C., Clark, S., Ghorbal, B., 2015. Cretaceous-Cenozoic sedimentary budgets of the Southern Mozambique Basin: implications for uplift history of the South African Plateau. Journal of African Earth Sciences, 109, 1-10. http://dx.doi.org/10.1016/j.jafrearsci.2015.05.007 
Sansom, P., 2018. Hybrid turbidite-contourite systems of the Tanzanian margin. Petroleum Geoscience. https://doi.org/10.1144/petgeo2018-044

Schlitzer, R., 2013. Ocean Data View. http://odv.awi.de

Schlüter, P., Uenzelmann-neben, G., 2008. Indications for bottom current activity since Eocene times: the climate and ocean gateway archive of the Transkei Basin, South Africa. Global and Planetary Change, 60, 3-4, 416-428. http://dx.doi.org/10.1016/i.gloplacha.2007.07.002

Schott, F.A., McCreary Jr., J.P., 2001. The monsoon circulation of the Indian Ocean. Progress in Oceanography, 51, 1, 1-123. http://dx.doi.org/10.1016/S0079-6611(01)00083-0

Schouten, M.W., de Ruijter, W.P.M., van Leeuwen, P.J., Ridderinkhof, H., 2003. Eddies and variability in the Mozambique Channel. Deep Sea Research Part II: Topical Studies in Oceanography, 50, 12-13, 1987-2003. http://dx.doi.org/10.1016/S0967-0645(03)00042-0

Schulz, H., Lückge, A., Emeis, K., Mackensen, A., 2011. Variability of Holocene to Late Pleistocene Zambezi riverine sedimentation at the upper continental slope off Mozambique, $15^{\circ}-21^{\circ} \mathrm{S}$. Marine Geology, 286, 1-4, 21-34. http://dx.doi.org/10.1016/j.margeo.2011.05.003

Shepard, F.P., 1963. Submarine Geology. Harper and Row, New York, $2^{\text {nd }}$ Edition, 557.

Shanmugam, G., 2013. Modern internal waves and internal tides along oceanic pycnoclines: challenges and implications for ancient deep-marine baroclinic sands. AAPG Bulletin, 97, 5, 799-843. http://dx.doi.org/10.1306/10171212101

Shanmugam, G., 2014. Modern internal waves and internal tides along oceanic pycnoclines: challenges and implications for ancient deep-marine baroclinic sands: reply. AAPG Bulletin, 98, 4, 858-879. http://dx.doi.org/10.1306/09111313115

Shchepetkin, A.F., McWilliams, J.C., 2005. The regional oceanic modeling system (ROMS): a split-explicit, free-surface, topography-following-coordinate oceanic model. Ocean Model, 947-404. http://dx.doi.org/10.1016/i.ocemod.2004.08.002

Sinha, M.C., Louden, K.E., Parsons, B., 1981. The crustal structure of the Madagascar Ridge. Geophysical Journal International, 66, 2, 351-377. http://dx.doi.org/10.1111/j.1365-246X.1981.tb05960.x

Stow, D.A.V., 1994. Deep sea processes of sediment transport and deposition, in: Kenneth, P. (Eds.), Sediment Transport and Depositional Processes. Blackwell Scientific Publications, Oxford, 257-291. ISBN: 0-632-03112-3

Stow, D.A.V., Faugères, J.C., Howe, J.A., Pudsey, C.J., Viana, A., 2002. Contourites, bottom currents and deep-sea sediment drifts: current state-of-the-art, in: Stow, D.A.V., Pudsey, C.J., Howe, J.A., Faugères, J.C., Viana, A.R. (Eds.), Deep-Water Contourite Systems: Modern Drifts and Ancient Series, Seismic and Sedimentary Characteristics. Geological Society of London, Memoirs, 22, 7-20. http://dx.doi.org/10.1144/GSL.MEM.2002.022.01.02

Stow, D.A.V., Hernández-Molina, F.J., Llave, E., Sayago, M., Díaz del Río, V., Branson, A., 2009. Bedform-velocity matrix: the estimation of bottom current velocity from bedform observations. Geology, 37, 4, 327-330. http://dx.doi.org/10.1130/G25259A.1

Swart, N.C., Lutjeharms, J.R.E., Ridderinkhof, H., de Ruijter, W.P.M., 2010. Observed characteristics of Mozambique Channel eddies. Journal of Geophyical Research, 115, 1-14. http://dx.doi.org/10.1029/2009JC005875

Talley, L., 1996. Antarctic intermediate water in the South Atlantic, in: Wefer, G., Berger, W.H., Siedler, G., Webb, D.J. (Eds.), The South Atlantic: Present and Past Circulation. Springer, Berlin, Heidelberg, 219-238. http://dx.doi.org/10.1007/978-3-642-80353-6 11

Ternon, J.F., Roberts, M.J., Morris, T., Hancke, L., Backeberg, B., 2014. In situ measured current structures of the eddy field in the Mozambique Channel. Deep Sea Research Part II: Topical Studies in Oceanography, 100, 10-26. http://dx.doi.org/10.1016/i.dsr2.2013.10.013

Toole, J.M., Warren, B.A., 1993. A hydrographic section across the subtropical South Indian Ocean. Deep-Sea Research Part I: Oceanographic Research Papers, 40, 10, 1973-2019. http://dx.doi.org/10.1016/0967-0637(93)90042-2 
Tucholke, B.E., Embley, R.W., 1984. Cenozoic regional erosion of the Abyssal Sea floor off South Africa, in: Schlee, J.S. (Eds.), Interregional Unconformities and Hydrocarbon Accumulation. AAPG Memoir 36, 145-164. http://dx.doi.org/10.1306/M36440C11

Uenzelmann-Neben, G., 2001. Seismic characteristics of sediment drifts: An example from the Agulhas Plateau, southwest Indian Ocean. Marine Geophysical Research, 22, 5-6, 323-343. http://dx.doi.org/10.1023/A:1016391314547

Uenzelmann-Neben, G. and Huhn, K., 2009. Sedimentary deposits on the southern South African continental margin: Slumping versus non deposition or erosion by oceanic currents? Marine Geology, 266, 6-79. http://dx.doi.org/10.2113/gssajg.114.3-4.449

Uenzelmann-neben, G., Watkeys, M.K., Kretzinger, W., Frank, M., Heuer, L., 2011. Paleoceanogrpahic interpretation of a seismic profile from the southern Mozambique ridge, southwestern Indian Ocean. South African Journal of Geology, 114, 34, 449-458. http://dx.doi.org/10.2113/gssajg.114.3-4.449

Ullgren, J.E., van Aken, H.M., Ridderinkohof, H., de Ruijter, W.P.M., 2012. The hydrography of the Mozambique Channel from six years of continuous temperature, salinity, and velocity observations. Deep Sea Research Part I: Oceanographic Research Papers, 69, 36-50. http://dx.doi.org/10.1016/i.dsr.2012.07.003

van Aken, H.M., Ridderinkhof, H., de Ruijter, W.P.M., 2004. North Atlantic deep water in the south-western Indian Ocean. Deep Sea Research Part I: Oceanographic Research Papers, 51, 6, 755-776. http://dx.doi.org/10.1016/j.dsr.2004.01.008

van Haren, H., Gostiaux, L., 2011. Large internal wave advection in very weakly stratified deep Mediterranean waters. Geophysical Research Letters, 38, 22. http://dx.doi.org/10.1029/2011GL049707

Viana, A.R., Almeida Jr., W., Nunes, M.C.V., Bulhões, E.M., 2007. The economic importance of contourites. Geological Society, London, Special Publication, 276, 1-23. http://dx.doi.org/10.1144/GSL.SP.2007.276.01.01

Walford, H.L., White, N.J., Sydow, J.C., 2005. Solid sediment load history of the Zambezi Delta. Earth and Planetary Science Letters, 238, 1-2, 49-63. http://dx.doi.org/10.1016/j.epsl.2005.07.014

Watkeys, M.K., Sokoutis, D., 1998. Transtension in southeastern Africa associated with Gondwana break-up. Geological Society of London, Special Publications, 135, 203-214. http://dx.doi.org/10.1144/GSL.SP.1998.135.01.13

Weatherall, P., Marks, K. M., Jakobsson, M., Schmitt, T., Tani, S., Arndt, J. E., Rovere, M., Chayes, D., Ferrini, V., Wigley, R., 2015. A new digital bathymetric model of the world's oceans. Earth and Space Science, 2, 8, 331-345. http://doi.org/10.1002/2015EA000107

Wiles, E., Green, A., Watkeys, M., Jokat, W., Krocker, R., 2014. A new pathway for Deep water exchange between the Natal Valley and Mozambique Basin? Geo-Marine Letters, 34, 6, 525-540. http://dx.doi.org/10.1007/s00367-014-0383-1

Wiles, E., Green, A.N., Watkeys, M.K., Jokat, W., 2017. Zambezi continental margin: compartmentalized sediment transfer routes to the abyssal Mozambique Channel. Marine Geophysical Research, 38, 3, 227-240. http://dx.doi.org/10.1007/s11001-016-9301-4

Wilson, A.M., Raine, R., Mohn, C., White, M., 2015. Nepheloid layer distribution in the Whittard Canyon, NE Atlantic Margin. Marine Geology, 367, 130-142. http://dx.doi.org/10.1016/i.margeo.2015.06.002

Xie, J., He, Y., Chen, Z., Xu, J., Cai, S., 2015. Simulations of internal solitary wave interactions with mesoscale eddies in the northeastern South China Sea. Journal of Physical Oceanography, 45, 12, 2959-2978. http://dx.doi.org/10.1175/JPO-D-15$\underline{0029.1}$

\section{FIGURE CAPTIONS}

Fig. 1. Location of study area and data collection sites. (A) Bathymetric map (ETOPO1 1 arc-minute global relief model; Amante and Eakins, 2009) of the southwest Indian Ocean indicating catchment areas of the Zambezi, Limpopo, and Tugela rivers basins. Yellow dots indicate examples with large contourite deposits in present-day (or recent) ocean basins and in 
the ancient sedimentary record generated by bottom currents. 1: Gruetzner and Uenzelmann-Neben, 2015; 2: Uenzelmann-Neben, 2001; 3: Schlüter and Uenzelmann-Neben, 2008; Niemi et al., 2000; 4: Flemming, 1978; 5: Preu et al., 2011; 6: Breitzke et al., 2017; Kolla et al., 1980; 7: Uenzelmann-Neben et al., 2011; 8: Uenzelmann-Neben and Huhn, 2009; (B) Bathymetric map (ETOPO1 1 arc-minute global relief model; Amante and Eakins, 2009) of the Mozambique Channel indicating position of the dataset interpreted and the main bathymetric features. The study area covered by highresolution multibeam data was interpreted based on Breitzke et al. (2017) and Wiles et al. (2017). Yellow dots show the location of the IODP Expedition 361 and DSDP Leg 25. Abbreviations: MozR = Mozambique Ridge; MdgR = Madagascar Ridge; and FZ = Fracture Zone.

Fig. 2. Bathymetric map (ETOPO1 1 arc-minute global relief model; Amante and Eakins, 2009) of the Mozambique Channel indicating schematic position of present-day water masses.

Fig. 3. Slope gradient map for surfaces dipping $\geq 2^{\circ}$ along the Mozambican continental margin. Bathymetric map includes the main physiographic domains (continental shelf; upper, middle, and lower continental slopes; and abyssal plain) and morphological features superimposed (ETOPO1 1 arc-minute global relief model; Amante and Eakins, 2009). The white line indicates the location of the buried Beira High. Abbreviations: $A L B=$ Almirante Leite Bank; $C T=$ Central Terrace; IT = Inharrime Terrace; LC = Limpopo Cone; MozR = Mozambique Ridge; NR = Naudé Ridge; and TC = Tugela Cone. $(\mathrm{A})$ to $(\mathrm{F})$ Bathymetric profiles showing seafloor morphology for the three different sectors: $(A)$ and $(B)$ are the northern sector, (C) and (D) the central sector, and (E) and (F) the southern sector.

Fig. 4. Morpho-sedimentary map of the Mozambique Channel. This map illustrates the complex morphology of the Mozambique Channel as well as the interplay between down- and along-slope processes. Contourite depositional, erosional, and mixed erosive-depositional features are indicated. Lineations based on Breitzke et al. (2017) and submarine canyons based on Wiles et al. (2017). Abbreviations: DFZ = Davie Fracture Zone and SCS = Submarine Canyon Systems.

Fig. 5. Examples of four multichannel seismic reflection profiles of the Mozambican continental margin from south (A) to north (D), showing the major morpho-sedimentary features. Horizontal scale is the same for all the profiles. (E) Inlay illustrating the D1 drift and the T1 terrace, as well as high amplitude reflection patterns (HARs) of contourite terrace T1. Location in Figs. 1 and 4 (section (A) courtesy of CGG Multi-client and New Ventures and sections (B, C), and (D) courtesy of INP and WesternGeco Multiclient).

Fig. 6. Examples of depositional, erosional, and mixed contourite features from multichannel seismic reflection profiles. Details of contourite terraces T1 and T2 in (A), T3 in (C), (D), and (E), and T4 in (G) and (H). Examples of plastered drift D1 are illustrated in (A), D2 in (A), (B), and (E), and D3 in (C) and (E). Moats and elongated-mounded drifts are shown in (B), (F), 

stacking pattern of plastered drift D2. Locations in Fig. 4 for (A-H), in Fig. 11 for (A, B, E, F, G) and (H). Abbreviation: HARs = High Amplitude Reflections. Profiles (A, B, F, G) and (H) courtesy of INP and WesternGeco Multiclient. Profiles (C-E) courtesy of CGG Multi-client and New Ventures.

Fig. 7. (A-C) Temperature $\left({ }^{\circ} \mathrm{C}\right)$ vs. salinity (psu) diagrams for southern, central, and northern sectors respectively. (D-E) Panel plots with neutral densities $\left(\mathrm{kg} / \mathrm{m}^{3}\right)$ vs. oxygen content $(\mathrm{ml} / \mathrm{l})$ along the Mozambican continental margin for data collected from hydrographic sections of the southern (D) and central (E) sectors. Deep water mass circulation denoted as: AABW $=$ Antarctic Bottom Water; NADW $=$ North Atlantic Deep Water; AAIW = Antarctic Intermediate Water; RSW = Red Sea Water; SICW = South Indian Central Water; TSW-STSW = Tropical Surface Water - Subtropical Surface Water.

Fig. 8. Seismic and hydrographic vertical sections for the Mozambican continental margin. The water column colour ranges indicate salinity (psu), temperature $\left({ }^{\circ} \mathrm{C}\right)$ and oxygen content $(\mathrm{ml} / \mathrm{l})$. These profiles are located in Fig. 1 . Water mass interpretations and major contourite features are indicated on the sections. Profile (A) courtesy of TOTAL and partners and Profiles (B, C) courtesy of INP and WesternGeco Multiclient.

Fig. 9. (A) Seismic and hydrographic vertical section for the Mozambican continental margin. Water column colour range indicates the buoyancy (Brunt-Väisälä) frequency (cycl/h). This profile is denoted as Fig. 6A located in Fig. 4. (B) Inlay illustrating the buoyancy (Brunt-Väisälä) frequency (cycl/h) along contourite terrace T1. Seismic line courtesy of INP and WesternGeco Multiclient. (C) Panel plots with Depth from pressure $(\mathrm{m})$ vs. neutral densities $\left(\mathrm{kg} / \mathrm{m}^{3}\right.$ ) and buoyancy (BruntVäisälä) frequency (cycl/h) at station 17802 (WOD13) located in Fig. 1. The yellow stripes indicate areas potentially correlated with internal wave generation at interfaces between Subtropical Surface Water (STSW) and South Indian Central Water (SICW), and between SICW and Antarctic Intermediate Water (AAIW).

Fig. 10. Select examples of internal waves (solitons) propagating along the Mozambique Channel. Images (A-C) are located along the Bay of Maputo (from Jackson, 2004) and (D-E) are along the Bight of Sofala (from Magalhaes et al., 2014). Abbreviations: $\mathrm{NMB}=$ Northern Mozambique Basin; $\mathrm{SMB}=$ Southern Mozambique Basin; $\mathrm{NV}=$ Natal Valley; MozR $=$ Mozambique Ridge; IWs = Internal waves.

Fig. 11. Results from the Regional Oceanic Modelling System (ROMS) showing mean bottom current velocities along the seafloor of five different sectors indicated in Fig. 4. sedimentation along the Mozambique Channel. Simplified morpho-sedimentary and hydrographic features are shown. (B) Schematic model for the Mozambique Channel explaining water mass interface processes. 
Table I. Neutral densities used to characterize water masses interacting with bathymetric features of the Mozambique

\begin{tabular}{c|cc}
\hline Water mass & $\begin{array}{c}\text { Water depth } \\
(\mathrm{m})\end{array}$ & $\gamma^{\eta}\left(\mathrm{kg} / \mathrm{m}^{3}\right)$ \\
\hline TSW\&STSW & $0-200$ & $23-25.8$ \\
SICW & $200-800$ & $26.4-26.8$ \\
& & \\
AAIW & $800-1500$ & $27-27.8$ \\
RSW & $900-1200$ & $\sim 27.4$ \\
NADW & $2200-3500$ & $>27.8$ \\
AABW & $>4000$ & $>28.2$ \\
\hline
\end{tabular}

1264

Table II. Morphological characteristics (shape, gradient and width) for the continental slope subdomains (upper, middle and lower slopes) of the southern, central and northern sectors within the study area. Letters (A-F) correspond to bathymetric profiles shown in Fig. 3.

\begin{tabular}{|c|c|c|c|c|c|c|c|c|c|}
\hline & \multicolumn{9}{|c|}{ Continental slope } \\
\hline & \multicolumn{3}{|c|}{ Upper Slope } & \multicolumn{3}{|c|}{ Middle Slope } & \multicolumn{3}{|c|}{ Lower Slope } \\
\hline & & Sectors & & & Sectors & & & Sectors & \\
\hline & Southern & Central & Northern & Southern & Central & Northern & Southern & Central & Northern \\
\hline Shape & $\begin{array}{l}\text { Concave } \\
\text { (F) / } \\
\text { convex } \\
\text { (E) }\end{array}$ & $\begin{array}{c}\text { Convex } \\
(C, D)\end{array}$ & $\begin{array}{l}\text { Convex } \\
\text { (B) / } \\
\text { concave } \\
\text { (A) }\end{array}$ & $\begin{array}{l}\text { Concave } \\
\text { (F) / } \\
\text { convex } \\
\text { (E) }\end{array}$ & $\begin{array}{c}\text { Convex } \\
(C, D)\end{array}$ & $\begin{array}{c}\text { Concave } \\
(\mathrm{A}, \mathrm{B})\end{array}$ & $\begin{array}{c}\text { Concave } \\
(E, F)\end{array}$ & $\begin{array}{c}\text { Convex } \\
(C, D)\end{array}$ & $\begin{array}{c}\text { Concave } \\
(\mathrm{A}, \mathrm{B})\end{array}$ \\
\hline $\begin{array}{l}\text { Gradient* } \\
\text { (degrees) }\end{array}$ & $\begin{array}{l}7.2^{\circ} / \\
1.5^{\circ}\end{array}$ & $1^{\circ}$ & $\begin{array}{l}2.6^{\circ} / \\
3.7^{\circ}\end{array}$ & $4.7^{\circ} / 1.4^{\circ}$ & $0.9^{\circ}$ & $1.4^{\circ}$ & $1.3^{\circ}$ & $1.1^{\circ}$ & $0.8^{\circ}$ \\
\hline $\begin{array}{l}\text { Width* } \\
\text { (km) }\end{array}$ & $\sim 4 / \sim 56$ & $\begin{array}{c}\sim 20 \text { to } \\
45\end{array}$ & $\begin{array}{c}25 / \\
\sim 10\end{array}$ & $\sim 6 / \sim 82$ & $\begin{array}{c}\sim 10 \text { to } \\
90\end{array}$ & $\begin{array}{c}\sim 15 \text { to } \\
50\end{array}$ & $\sim 10$ & $\begin{array}{c}\sim 10 \text { to } \\
70\end{array}$ & $\begin{array}{c}\sim 70 \text { to } \\
170\end{array}$ \\
\hline
\end{tabular}

*Represents average data 







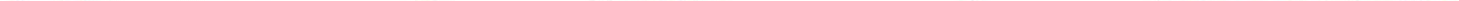









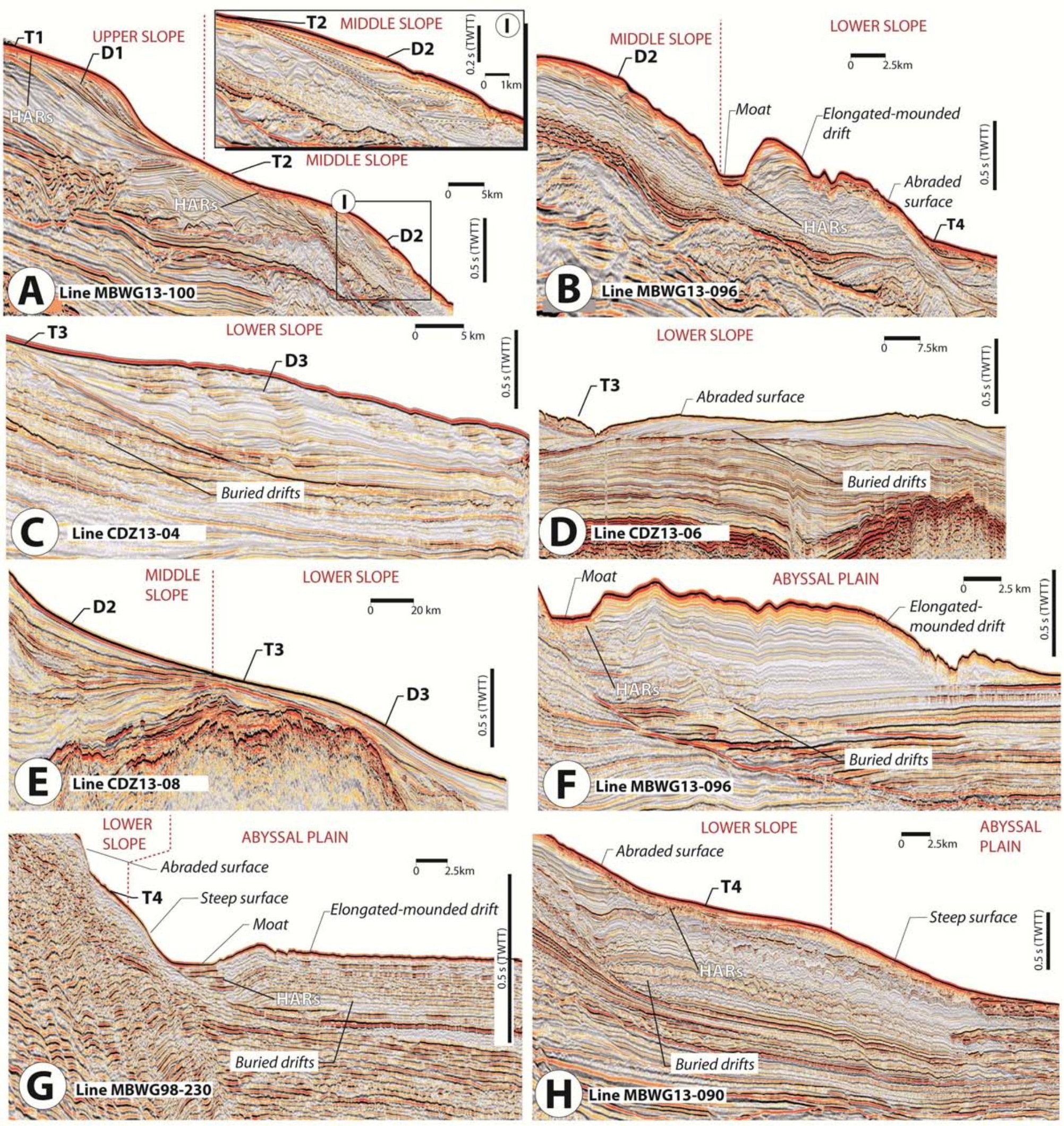


Temperature $\left({ }^{\circ} \mathrm{C}\right)$

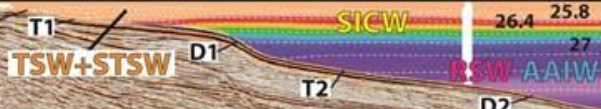

A
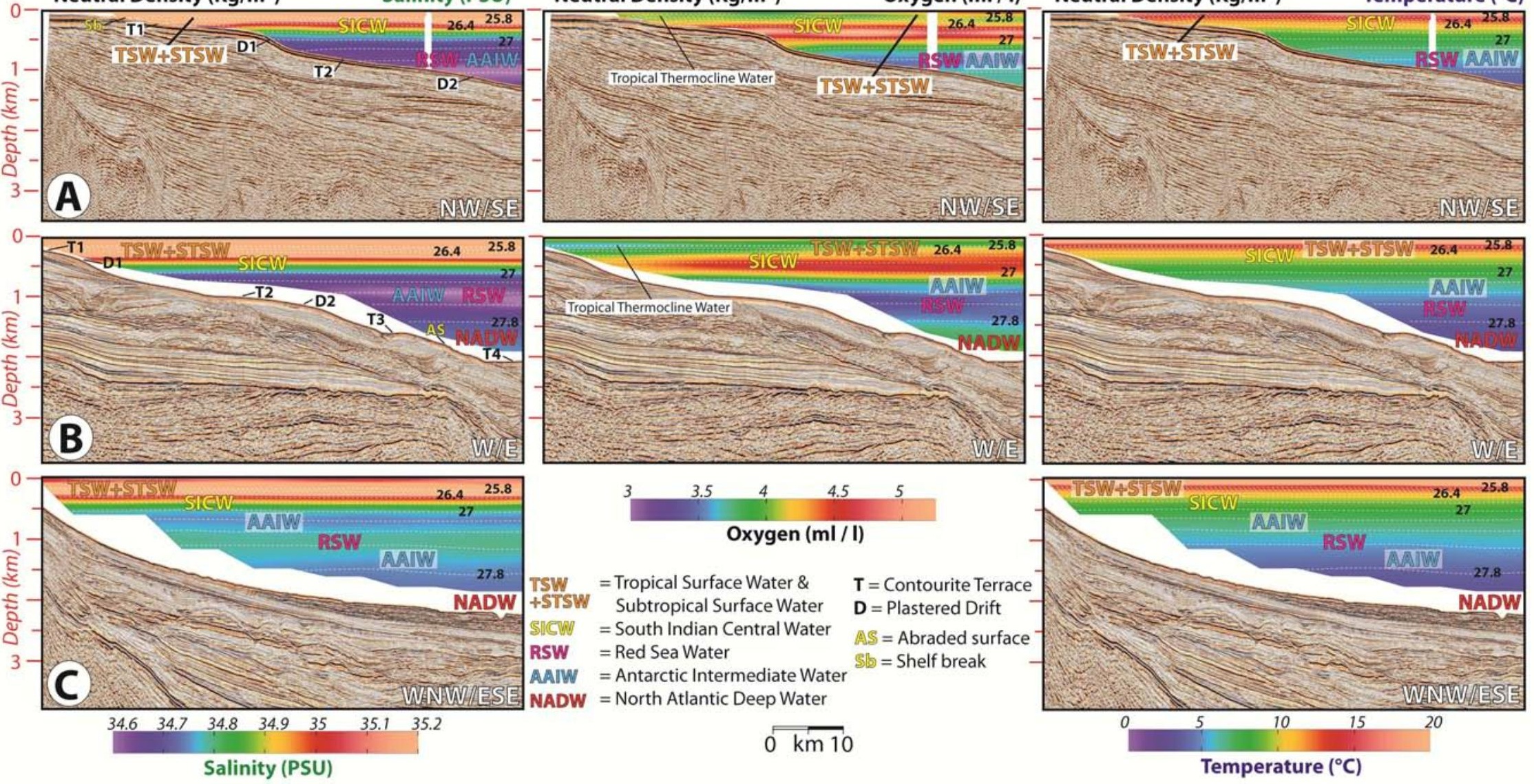

Salinity (PSU) 


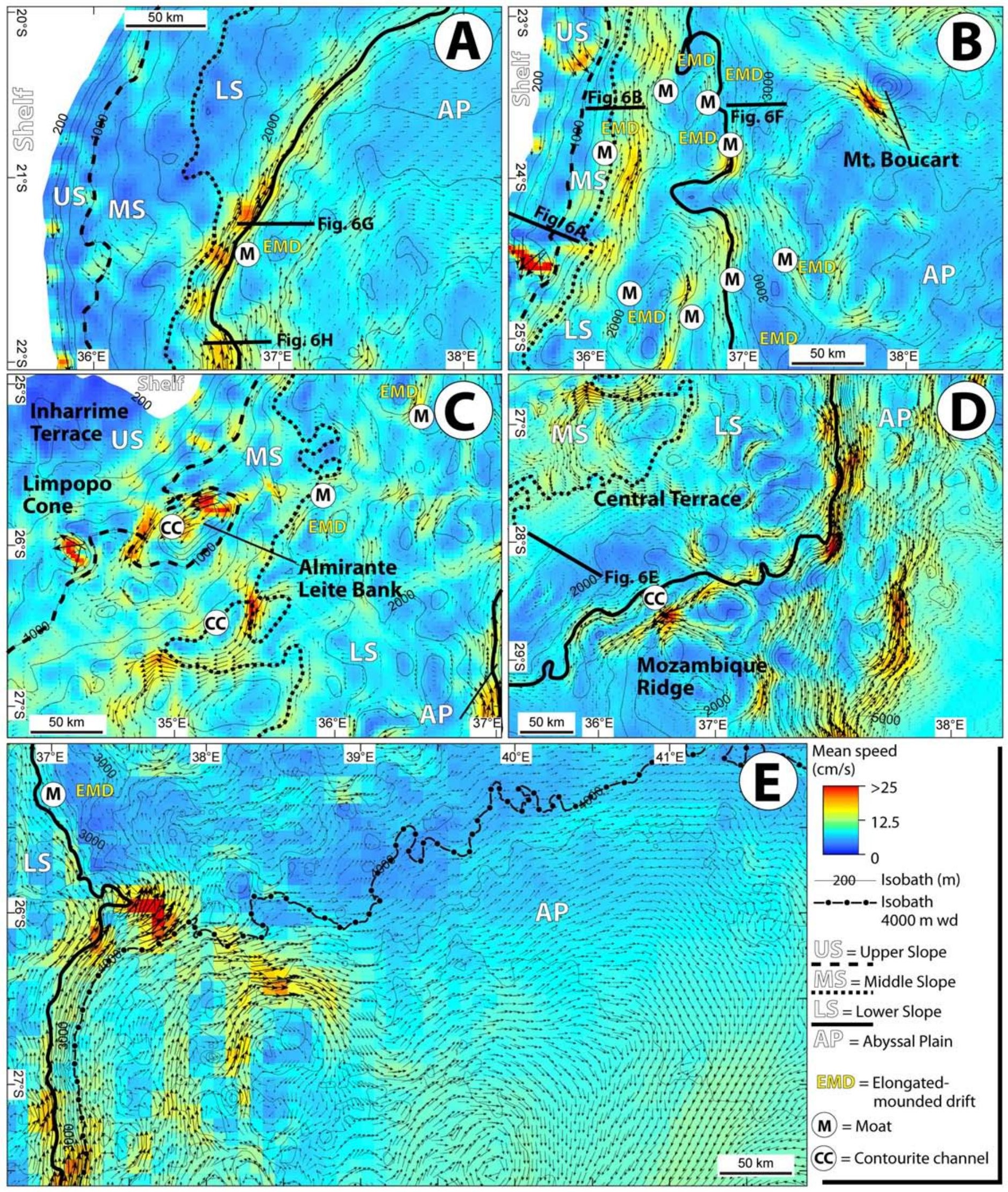





\section{Highlights:}

- Combined study of the geomorphology, sedimentology, and physical oceanography of the Mozambique Channel.

- Bottom circulation of water masses and associated sedimentary processes shape the continental margin.

- Interface positions of water-masses with contrasting densities (i.e., internal waves) sculpt terraces along the slope at a regional scale.

- Morphologic obstacles play an essential role in local water mass behaviours and dynamics. 